\title{
Wybrane kolekcje historyczne z zakresu historii medycyny i farmacji we współczesnych zbiorach muzealnych i bibliotekach naukowych Stambułu - część druga ${ }^{1}$
}

\author{
Selected historical collections in the field of the history \\ of medicine and pharmacy in the contemporary museum \\ collections and scientific libraries of Istanbul. Part two
}

\begin{abstract}
Summary
In the collections of Turkish public scientific institutions, museums and libraries, there are extensive resources of historical artifacts connected thematically with the history of medicine and pharmacy. They include mainly manuscript books in Arabic, Persian, Turkish and also in Greek and Latin, which were gathered in the capital of the Ottoman Empire. The historical and medical collections contain also numerous printed books, including critical editions of the work by the classic authors of Islamic medicine together with their translations into congressional languages. In Istanbul, we can also find numerous examples of various types of devices and equipment used in connection with the treatment and production of medicines. The article consists of two parts. The first part presents the outline of the history of the evelopment of historical collections in Istanbul connected with the history of medicine and pharmacy. The second part describes selected museum facilities and collections.
\end{abstract}

1 Artykuł powstał $\mathrm{w}$ ramach programu badawczego Uniwersytetu Medycznego im. Piastów Śląskich we Wrocławiu, nr SUB.D210.21.104. 
Słowa kluczowe: historia medycyny i farmacji w Turcji, kolekcje historyczne Stambułu

Key words: history of medicine and pharmacy in Turkey, historical collections of Istanbul

\section{Wybrane muzea Stambułu i ich kolekcje związane tematycznie z historią medycyny i farmacji}

W drugiej części artykułu przedstawię szerzej cztery muzea związane tematycznie $\mathrm{z}$ historią medycyny i farmacji. Pierwszym z nich będzie duże muzeum publiczne, finansowane ze środków państwowych i przez sponsorów prywatnych, biletowane i dostępne dla szerokiej publiczności - Muzeum Historii Nauki i Techniki Islamu. Dwa następne muzea mają status placówek uczelnianych. Są znacznie mniejsze, a zarówno ich powstanie, jak i praktyczne funkcjonowanie jest podporządkowane celom dydaktycznym. Historia medycyny i farmacji należy bowiem do przedmiotów obowiązkowych w programie nauczania studentów wydziałów lekarskich i farmaceutycznych na tureckich uniwersytetach ${ }^{2}$. Właścicielem Muzeum Historii Farmacji oraz Muzeum Historii Medycyny i Farmacji jest Uniwersytet Stambulski, który w pełni pokrywa koszty ich działalności. Są to placówki niebiletowane, o ograniczonej dostępności dla zwiedzających spoza grona pracowników i studentów tej uczelni. Oba muzea można jednak zwiedzać po wcześniejszym umówieniu się, telefonicznym lub mailowym, z ich pracownikami. Czwartym muzeum, które zostanie omówione w tej części artykułu, jest Muzeum Hammamu. Należy ono do Uniwersytetu Stambulskiego. Koszty jego utworzenia w dużej części zostały pokryte z budżetu miasta Stambuł, a koszty utrzymania są dofinansowane przez różnych sponsorów instytucjonalnych. Muzeum jest otwarte dla szerokiej publiczności, niebiletowane, zwiedzanie jest możliwe nie tylko w grupach, lecz także przez indywidualnych odwiedzających.

\section{Muzeum Historii Nauki i Techniki Islamu w Stambule}

Koncepcja stworzenia Muzeum Historii Nauki Islamskiej w Stambule zrodziła się w 2003 r. $^{3}$, po zapoznaniu się przez uczonych i człon-

${ }^{2}$ E. Erbay, The Role of Medical Museum in the Education of Medicine, [w:] A. Musajo-Somma (red.), The 39th International Society of History of Medicine Congress on the History of Medicine 5-10 September 2004, Italia, Bari 2005, s. 99-102.

${ }^{3}$ F. Sezgin, The Istanbul Museum for the History of Science and Technology in Islam (An Overview), Culture Co., Istanbul 2010, s. 6. 
Wybrane kolekcje historyczne z zakresu historii medycyny i farmacji...

ków władz tureckich z ekspozycją o podobnym charakterze stworzoną w 1982 r. w Instytucie Historii Nauki Arabsko-Islamskiej, funkcjonującym w strukturze Uniwersytetu Johanna Wolfganga Goethego we Frankfurcie nad Menem w Niemczech ${ }^{4}$. Główną ideą, wokół której koncentrowała się ta ekspozycja, była rekonstrukcja urządzeń technicznych opisanych w dziełach autorów związanych z islamskim kręgiem kulturowym, powstałych między IX a XVI w. Ekspozycja miała dokumentować recepcję standardu nauki greckiej przez uczonych pochodzących z państw zarządzanych przez władców muzułmańskich ${ }^{5}$. Głównymi dziełami, na podstawie których dokonano tej rekonstrukcji, były manuskrypty: Kita bat-Tasrif z X w., którego autorem był Abu l-Quasim az-Zahravi, al-Jami'bain al-'ilm wa-l-'amal autorstwa Ibn ar-Razzaz al-Jazariego z XII w. oraz Jami' al-mabadi' wa-l-ghayat Abu l-Hasana al-Marrakushiego z XIII w. Badania frankfurckie były kontynuacją prowadzonych wcześniej. Do ich pionierów należał Eilhard Wiedemann, fizyk z Erlangen, który prowadził je w latach 1875-1928. Około 1900 r. Wiedemann rozpoczął prace nad rekonstrukcją dawnych urządzeń naukowych wykonanych przez uczonych islamskich. Pierwsze $\mathrm{z}$ tych rekonstrukcji zostały zaprezentowane $\mathrm{w}$ Muzeum Niemieckim (Deutsches Museum) w Monachium. W latach 30. XX w. badania $\mathrm{w}$ tym kierunku rozpoczął Fuat Sezgin, późniejszy profesor orientalistyki i islamistyki w Turcji. W 1938 r. wykonał rekonstrukcje na podstawie dawnych rękopisów ok. 30 urządzeń naukowych. Nie kontynuował jednak tej pracy z powodu braku środków finansowych.

Badania nad dawnym standardem naukowym nauki islamskiej były kontynuowane w powojennych Niemczech. Do 2003 r. na Uniwersytecie we Frankfurcie nad Menem opracowano już 800 rekonstrukcji dawnych urządzeń technicznych związanych z islamskimi uczonymi. Nie były one jednak szerzej dostępne dla zwiedzających. Mogli oni zapoznać się ze zgromadzoną kolekcją tylko okazjonalnie, przy okazji Dni Otwartych Drzwi Uniwersytetu we Frankfurcie. W ciągu 12 lat ekspozycję obejrzało tysiące zwiedzających, co potwierdziło jej atrakcyjność. W 2003 r. opublikowano katalog wystawy, zatytułowany Wissenschaft und Technik im Islam. W 2004 r. ten sam katalog wydano w języku francuskim. W następnych latach ukazały się wydania angielskie i arabskie. W 2005 r. ekspozycję frankfurcką zwiedził ów-

${ }^{4}$ Ibidem, s. 6-8.

${ }_{5} \mathrm{O}$ skali recepcji nauki grecko-rzymskiej $\mathrm{w}$ islamskim kręgu kulturowym por. R. Rashed (red.), Historia nauki arabskiej, t. 3, Technika, alchemia, nauki przyrodnicze i medycyna, tłum. J. Kozłowska, K. Pachniak, Wydawnictwo Dialog, Warszawa 2005. 
czesny Minister Kultury i Turystyki Republiki Tureckiej Atilla Koc, który postanowił spróbować stworzyć podobne muzeum w Turcji. Poparcie dla tej idei wyraziły Turecka Akademia Nauk (TÜBA) i Urząd do Spraw Badań w dziedzinie Nauki i Techniki (The Scientific and Technology Research Council of Turkey - TÜBITAK). W 2006 r., przy poparciu władz Stambułu, została podjęta decyzja o remoncie zabytkowego budynku w Parku Gülhane, z przeznaczeniem na Muzeum Nauki i Techniki Islamskiej. W 2007 r. zostały podpisane wszystkie oficjalne dokumenty, a rekonstrukcja uzyskała dotację ze środków państwowych. Organizacja Muzeum została w znacznym stopniu dofinansowana przez prywatnego sponsora z USA, Araba z pochodzenia, który sfinansował $80 \%$ wszystkich znajdujących się obecnie w stambulskich zbiorach rekonstrukcji dawnych instrumentów naukowych. W 2008 r. otwarto Muzeum. Zostało zlokalizowane w centrum miasta, na terenie parku Gülhane, położonego między kompleksem pałaców sułtańskich Topkapı a budynkami utworzonego w końcu XIX w. Muzeum Archeologicznego. Możemy stwierdzić podobieństwo w genezie Muzeum Historii Nauki i Techniki Islamu i Muzeum Archeologicznego w Stambule. Obie placówki powstały na wzór już istniejących placówek europejskich o podobnej tematyce, a w ich genezie dużą rolę odgrywały nie tylko względy naukowe, lecz także prestiżowe. Wspaniała lokalizacja Muzeum Historii Nauki i Techniki Islamu w Stambule - w pobliżu najważniejszych zabytków historycznych miasta: kościoła Hagia Sophia, pałacu sułtanów Topkapı, Błękitnego Meczetu oraz podziemnej cysterny Basilika - podkreśla prestiżowy charakter tej placówki. Jest ona otwarta dla zwiedzających pięć dni w tygodniu, a zwiedzający mogą nabyć $\mathrm{w}$ Muzeum pięknie wydany katalog w języku angielskim.

Celem stambulskiej ekspozycji jest dokonanie rewizji stanu badań nauki zachodnioeuropejskiej $\mathrm{w}$ zakresie średniowiecznej recepcji osiągnięć starożytnej nauki i techniki. W zachodnioeuropejskiej historiografii nauki nadal dominuje ujęcie średniowiecza jako tzw. wieków ciemnych, w których klasyczna nauka starożytna uległa zapomnieniu, a jej ogólny standard zapaści, przezwyciężonej dopiero w okresie renesansu. Według twórców scenariusza wystawy w Muzeum Historii Nauki i Techniki Islamu w Stambule jest to teza błędna. Nie uwzględnia ona bowiem pokaźnego dorobku uczonych związanych z muzułmańskim kręgiem kulturowym, powstałego między VII a XVI w. Uzasadnieniem takiego stanowiska naukowców europejskich jest fakt, iż dorobek większości uczonych islamskich (poza tymi autorami, którzy 
zostali przyswojeni nauce europejskiej już w średniowieczu) pozostaje Europejczykom niemal całkowicie nieznany ze względu na brak znajomości języków orientalnych: arabskiego, perskiego, tureckiego i innych, w których zostały spisane rękopiśmienne monografie odzwierciedlające dorobek naukowy powstały w środowisku islamskim. Częściowo sytuacja ta uległa zmianie na przełomie XIX i XX w., wraz $\mathrm{z}$ pojawieniem się $\mathrm{w}$ Europie profesjonalnych studiów orientalistycznych. Wyniki badań orientalistów europejskich nie zdołały się jednak przebić $\mathrm{w}$ dostatecznym stopniu do zachodnioeuropejskiej historiografii nauki ani do podręczników szkolnych. Było wśród nich bowiem niewielu naukoznawców. Nie zostały więc w związku z tym szerzej spopularyzowane w historiografii powszechnej, wpływając na potoczne postrzeganie średniowiecza jako okresu zastoju w rozwoju myślenia naukowego i załamania praktyki naukowej.

Głównym celem ekspozycji Muzeum Historii Nauki i Techniki Islamu w Stambule jest weryfikacja tej tezy - ukazanie ogromnego zakresu recepcji w nauce i technice islamskiej, uprawianej między VII a XVI w., standardu starożytnej nauki greckiej oraz dokonań naukowych wywodzących się sprzed ukształtowania się jej standardu (tj. sprzed VII w. p.n.e.). Odczytanie przez orientalistów manuskryptów spisanych $\mathrm{w}$ średniowieczu przez autorów arabskich, perskich i tureckich (a także pochodzących z innych krajów islamskich) wykazało bowiem, że średniowieczni muzułmańscy kopiści, komentatorzy i kompilatorzy korzystali nie tylko z dzieł wytworzonych w Grecji i Rzymie, a następnie w Bizancjum, lecz także stworzonych na innych obszarach kulturowych i to wcześniej, niż powstało klasyczne europejskie przyrodoznawstwo. W zbadanych (a niektórych przetłumaczonych na współczesne języki kongresowe) islamskich naukowych manuskryptach odnaleziono ślady recepcji odkryć, wynalazków i urządzeń technicznych stworzonych w Mezopotamii (kulturze Sumerów, Babilończyków i Asyryjczyków), w Anatolii (Hetytów), na Bliskim Wschodzie (Kanaanejczyków i Aramejczyków) oraz w Afryce Pó1nocnej (przede wszystkim Egipcjan). Austriacki historyk nauki Otto Neugebauer stwierdził, że czas powstania wielu z odkryć i wynalazków, przypisywanych dawniej nauce greckiej, należałoby przenieść o 2,5 tysiąca lat wstecz ${ }^{6}$ i uznać grecką starożytną kulturę naukową nie za oryginalną, ale receptywną, $\mathrm{w}$ której zostały z powodzeniem przyswojone osiągnięcia naukowe wcześniejszych wschodnich cywilizacji, przede wszystkim egipskiej.

\footnotetext{
${ }^{6}$ Ibidem, s. 9.
} 
Wystawa stambulskiego Muzeum Historii Nauki i Techniki kładzie nacisk na odtworzenie dorobku naukowego i technicznego średniowiecznej nauki islamskiej, nie tylko arabskiej, lecz także perskiej, tureckiej czy tadżyckiej. W ekspozycji został też uwzględniony dorobek uczonych chrześcijańskich i żydowskich, żyjących w średniowiecznych państwach islamskich. Autorzy większości dzieł naukowych, z których korzystano przy tworzeniu stambulskiej ekspozycji muzealnej, pozostają Europejczykom nieznani. Spopularyzowały się bowiem w Europie nazwiska tylko tych spośród nich, których dorobek został przyswojony jeszcze $\mathrm{w}$ średniowieczu, został przetłumaczony na łacinę, a nazwiska autorów przetłumaczonych dzieł zostały wówczas zlatynizowane. Wystawa stwarza w związku z tym możliwość znacznego poszerzenia dostępnej dotąd Europejczykom (poza wąskim kręgiem specjalistów - orientalistów) wiedzy dotyczącej historii nauki powstałej między VII a XVI w. w islamskim kręgu kulturowym.

Dla twórców ekspozycji Muzeum Historii Nauki i Techniki Islamu apogeum rozwoju nauki islamskiej, opartej na recepcji dawnych i obcych wzorców, przypada na $\mathrm{X}$ w. n.e. W późniejszych pięciu stuleciach ma miejsce, ich zdaniem, już jej oryginalny rozwój. Za najbardziej wpływowego uczonego z okresu klasycznego, starożytnego standardu nauki europejskiej, który przyczynił się do stworzenia rudymentów myślenia naukowego w islamskim kręgu kulturowym, przez twórców wystawy uznawany jest Arystoteles. Za najbardziej wpływowych lekarzy - Hipokrates i Galen. Stworzony przez nich model nauki opartej na doświadczeniu i obserwacji stał się podstawą muzułmańskiej koncepcji nauk przyrodniczych, $\mathrm{w}$ tym medycyny i farmacji. Podkreślając to wspólne, starożytne dziedzictwo, autorzy wystawy wskazują na jego perfekcyjne doskonalenie $\mathrm{w}$ średniowiecznej nauce islamskiej, co stwarza podstawę dla odrzucenia sposobu definiowania tej epoki jako „wieków ciemnych”.

Realizacja celu wystawy stała się podstawą jej szczegółowego planu. W salach rozmieszczonych na dwóch piętrach zabytkowego budynku znajdują się zabytki odzwierciedlające dokonania uczonych islamskich w poszczególnych dziedzinach nauki i techniki. Niektóre sale dokumentują wiedzę o świecie (geografia, mineralogia, fizyka) i o możliwościach technicznego wykorzystania zasobów naturalnych (chemia, medycyna i farmacja i in.). Ogólny schemat ekspozycji we wszystkich salach jest taki sam. W szklanej gablocie znajduje się rękopis napisany po arabsku, persku, tadżycku, turecku (lub w innym języku orientalnym), w którym zostało opisane dane osiągnięcie lub 
urządzenie naukowe. W gablocie znajduje się także jego opis w języku tureckim i angielskim. Czasami towarzyszy mu kopia schematycznego rysunku danego urządzenia, wykonanego odręcznie przez autora średniowiecznego manuskryptu jako ilustracja do jego dzieła. Obok źródła pisanego została umieszczona rekonstrukcja urządzenia, które zostało w tym źródle opisane. Towarzyszą jej współczesne opisy jego działania, różnego rodzaju schematy itp. Dopełnieniem przedstawienia jednego urządzenia lub wynalazku jest jego model, wykonany $\mathrm{w}$ skali umożliwiającej jego umieszczenie w gablocie. Wiele z eksponowanych modeli można uruchomić za pomocą specjalnego przycisku, co pozwala lepiej zorientować się w efektach ich pracy. Ekspozycja Muzeum Historii Nauki i Techniki Islamu pozwala m.in. na odtworzenie historii dawnych technik produkcji leków, które są przedstawiane $\mathrm{w}$ dziale poświęconym historii chemii. Muzeum zawiera np. modele urządzeń stosowanych do destylacji. Możemy tu również znaleźć przykłady urządzeń technicznych, które wykorzystywano do obróbki termicznej roślin z wykorzystaniem pary, a także wiele innych.

Wśród autorów dzieł naukowych, których dorobek z zakresu nauk przyrodniczych stał się podstawą rekonstrukcji, znajduje się m.in. Ibn al-Haitam (?- ok. 1041), uznany przez Heinricha Schippergesa za umysłowość na miarę Galileusza7. Ibn al-Haitam był twórcą i popularyzatorem $\mathrm{w}$ islamskim kręgu naukowym metodologii opartej na podstawach doświadczalnych, wyprowadzanej z arystotelizmu. Jego postać pozostała jednak Europejczykom nieznana. W ekspozycji muzeum znajdują się także fragmenty dzieł Jabira ibn Hayyana (VIII w.), twórcy podstaw standardu chemii, uprawianego w średniowiecznej nauce islamskiej. Jego dorobek był poznany i przyswojony w nauce europejskiej już w średniowieczu. Był znany pod zlatynizowanym imieniem Geber. W Muzeum znajdują się także fragmenty dzieł innego uczonego, związanego z islamskim kręgiem kulturowym, który wywarł duży wpływ na średniowieczną medycynę europejską - Awicenny (Ibn Sina), którego dzieło Quanun zostało przetłumaczone na łacinę (Kanon medicinae) i było przez kilka wieków rozpowszechniane w setkach kopii. Wiele rekonstrukcji prezentowanych w muzeum dotyczy miar i wag, z których korzystano m.in. przy produkcji leków, a także wynalazków technologicznych, które służyły wydobyciu z surowców leczniczych „materii medycznej” o odpowiednich właściwościach ${ }^{8}$. Do rekonstrukcji posłużyły m.in. dzieła takich autorów, jak

\footnotetext{
7 Ibidem, s. 23.

${ }^{8}$ Ibidem, s. 125-138.
} 
al-Khazini czy al-Biruni. Znajdujemy też wiele urządzeń optycznych, z których korzystano m.in. po to, aby wyjaśnić w sposób naukowy mechanizm wzroku ${ }^{9}$ czy sposób rozprzestrzeniania się światła.

Oddzielna ekspozycja została poświęcona medycynie ${ }^{10}$. Wykorzystano w jej przygotowaniu dzieła takich autorów, jak wspomniany już Awicenna, a także Abu Bakr ar-Razi (w zlatynizowanej wersji Rhazes), Abu l-Quasim az-Zahrawi (Albucasis), Dioscorides (w tłumaczeniu arabskim), Ishak ben Imran z Bagdadu, Abdalmalik Ibn Zuhra (łać. Avenzoar), Muhammed ben Ahmed ben Muhammed Ibn Rusd (łać. Awerroes), Ali ben Abi l-Hasa Ibn an-Nafis al. Qurasi, Abu Zaid Ahmad ben Sahl al-Balhi, al-Gazari i wielu innych. Możemy zapoznać się z przykładami opisywanych w ich dziełach wynalazków służących do leczenia i rehabilitacji, narzędzi operacyjnych, a także tablic anatomicznych.

Informacje dotyczące historii farmacji możemy natomiast odnaleźć w dziale poświęconym historii chemii ${ }^{11}$. Do najciekawszych obiektów ekspozycji dotyczącej tej dziedziny nauki należą urządzenia służące do destylacji, wyprażania, suszenia, kąpieli wodnej, skraplania, wypalania, podgrzewania itp. Zaprezentowano działające modele opisywanych przez średniowiecznych autorów islamskich urządzeń, które można obserwować przy pracy. Ekspozycja obejmuje też kilkadziesiąt rodzajów naczyń szklanych o różnych kształtach, dostosowanych do funkcji, które miały spełniać. Prezentowane są także naczynia gliniane oraz naczynia łączące w swojej budowie szkło i glinę.

Omawiana powyżej ekspozycja stanowi doskonały przykład konstruowania wystawy zgodnie $\mathrm{z}$ wcześniej sformułowanym planem, służącym realizacji ściśle określonego celu. Celem tym było ukazanie w jak najszerszym zakresie dorobku uczonych związanych z islamskim kręgiem kulturowym i przedstawienie ich działalności jako opartej na rozwiniętej podbudowie metodologicznej. Metodologia nauk przyrodniczych, w tym medycyny, farmacji i chemii, będąca podstawą nauki uprawianej $\mathrm{w}$ islamskim kręgu kulturowym, przedstawiana jest jako tożsama z metodologią rozwijaną przez najwybitniejszych uczonych Europy łacińskiej oraz Bizancjum, będącą podstawą nauczania na średniowiecznych europejskich uniwersytetach, a ostatecznie tworzącą podstawy rozwoju nowożytnego modelu europejskiego przyrodoznawstwa. Muzeum Historii Nauki i Techniki Islamskiej przedstawia

\footnotetext{
${ }^{9}$ Ibidem, s. 139-145.

${ }^{10}$ Ibidem, s. 147-171.

11 Ibidem, s. 173-184.
} 
naukę tworzoną w islamskim kręgu kulturowym jako europejską, tyle że tworzoną przez uczonych opierających swój światopogląd na innej religii niż chrześcijaństwo. Nie przeszkadzało to jednak recepcji w nauce islamskiej wzorców greckich (a za ich pośrednictwem egipskich i mezopotamskich) ani recepcji dokonań uczonych islamskich w łacińskim czy bizantyjskim kręgu kulturowym. Umożliwiała to wspólna metodologia (arystotelizm), wyznaczająca zasadnicze ramy metodologiczne uprawiania działalności naukowej. Muzeum nie jest jeszcze dostępne on-line. Osoby zainteresowane mogą natomiast kupić pięknie opracowany katalog zbiorów, napisany przez tureckiego orientalistę, prof. Fuata Sezgina.

\section{Muzeum Farmacji Wydziału Farmaceutycznego Uniwersytetu w Stambule}

Muzeum Farmacji Uniwersytetu w Stambule nie jest placówką otwartą dla szerokiego kręgu zwiedzających ${ }^{12}$. Zwiedzanie jest bezpłatne. Jest możliwe po wcześniejszym umówieniu się, telefonicznym lub internetowym. Zwiedzanie jest możliwe z grupach. Muzeum zapewnia przewodników oprowadzających zwiedzających w języku tureckim, angielskim lub niemieckim. Jest zlokalizowane w historycznym budynku Wydziału Farmaceutycznego, znajdującym się w bezpośrednim sąsiedztwie głównego kampusu uniwersyteckiego. Prezentowana w nim ekspozycja jest znacznie skromniejsza niż w poprzednio omawianym Muzeum Historii Nauki i Techniki Islamu. Jej stworzeniu przyświecały jednak inne cele, dla których prezentacji przeznaczona na ekspozycję przestrzeń wydaje się wystarczająca. Muzeum dokumentuje inny niż poprzednio prezentowany etap $\mathrm{w}$ historii nauk przyrodniczych w Turcji, a mianowicie okres przyspieszonej recepcji współczesnego standardu nauki europejskiej, przypadający na XIX stulecie i 1 połowę XX w. ${ }^{13}$

${ }^{12}$ F. Erbay, Istanbul Exhibitions as a Rescue for the History of Medicine, [w:] A.D. Erdemir, S. Erer, Ö. Usmanbas, A. Akgün (red.), 5th Balkan Congress on the History \& Ethics of Medicine 11-15 October 2011 Istanbul. Abstracts and Proceedings Book, Nobel Tip Kitabelveri Ltd., Istanbul 2012, s. 175-183.

${ }_{13}$ B. Sen, M. Nicolas, A. Mat, Les Relations Academiques en Pharmacie entre la France et la Turquie, [w:] A. Mat, H. Tekiner, B. Sen (red.), The Exchange of Pharmaceutical Knowledge between East and West. Proceedings 42nd International Congress for the History of Pharmacy 8-11 September 2015 Istanbul, Maestro Advertising Co., Istanbul 2016, s. 559-562; B. Sen, Deutsch-Türkische Beziehungen in der Pharmazie, [w:] A. Mat, H. Tekiner, B. Sen (red.), op. cit., s. 349-355; A. Terzioglu, E. Lucius (red.), Österreichisch-Türkische Medizinische Beziehungen. Berichte des Symposiums von 28. und 29. April 1986 in Istanbul, University of Istanbul, Istanbul 1987; A. Kernbauer, Die 
Muzeum Farmacji Uniwersytetu w Stambule zajmuje I piętro budynku, zbudowanego $\mathrm{w}$ latach 30 . XIX w. i oddanego do użytku w 1839 r., przeznaczonego dla pierwszej w Turcji szkoły wyższej, kształcącej farmaceutów według zachodnioeuropejskiego programu nauczania, zgodnego z ówczesnym europejskim standardem medycyny klinicznej. Utworzenie tej szkoły było jednym z podstawowych elementów modernizacji tureckiej medycyny i farmacji według wzorców europejskich. Plan ekspozycji został stworzony w celu udokumentowania tego procesu. W Muzeum zostały odtworzone kolejne jego etapy.

Pierwszym jest okres, w którym farmacja była wykładana w Stambule przez zagranicznych wykładowców, prowadzących nauczanie w języku niemieckim lub francuskim. W muzealnych gablotach zostały zgromadzone liczne, wydane w Europie Zachodniej w XIX w. podręczniki chemii, farmakognozji i farmacji stosowanej, napisane po niemiecku lub francusku. Wśród wykładowców stambulskiej Szkoły Farmacji, która w 1863 r. została włączona do Uniwersytetu Stambulskiego, stając się podstawą Wydziału Farmaceutycznego, już w latach 40. i 50. XIX w. znajdowali się również rodowici Turcy. Wywodzili się spośród stypendystów, kształconych w Niemczech, Austrii oraz we Francji. Korzystali oni z podręczników wydawanych na zachodzie Europy, pracując jako asystenci zagranicznych wykładowców, a także ich tłumacze. Gdy latach 60 . XIX w. rozpoczęto nauczanie farmacji w Stambule w języku tureckim, zaczęły się pojawiać pierwsze tureckie podręczniki. Zgromadzona w Muzeum ekspozycja odzwierciedla przebieg opisanego powyżej procesu. Integralną częścią ekspozycji są archiwalne zdjęcia tureckich studentów farmacji, mających tworzyć podwaliny nowoczesnego standardu tej dziedziny nauki w swoim kraju, dyplomy, odznaczenia i inne dokumenty osobiste, tworzące korpus zabytków o charakterze prywatnym, ilustrujących tworzenie się społeczności tureckich farmaceutów jako grupy o wyraźnie sprecyzowanych tradycjach zawodowych i samoświadomości.

Plan wystawy w Muzeum Farmacji ukazuje też następny istotny aspekt procesu modernizacji farmacji $\mathrm{w}$ Turcji, jakim było stworzenie nowoczesnych aptek, urządzonych i wyposażonych tak, jak w Europie. Różniły się one w sposób istotny od wcześniej istniejących w Turcji aptek opartych na wzorcach rodzimych. Europejski model apteki

Beziehungen österreichischer Universitäten, im besonderen jener von Prag und Graz, zur Universität Istabul, [w:] A. Terzioglu (red.), Proceedings of the International Symposiom: Istanbul University and the European Universities on the Occasion at the 550th Anniversary of the Foundation of Istanbul University, University of Istanbul, Istanbul 2004, nlb. 
był bowiem w XIX stuleciu zestandaryzowany, czego odzwierciedleniem był określony układ mebli aptecznych i sposób ich konstrukcji, dostosowany do przechowywania w nich w ściśle określonych miejscach wyróżnionych rodzajów substancji używanych do produkcji leków oraz produktów gotowych. Muzeum Farmacji przedstawia zwiedzającym przykłady XIX-wiecznych mebli aptecznych wykonanych w europejskich fabrykach i sprowadzonych do Turcji. Próżno w ich stylistyce doszukiwać się jakichkolwiek elementów orientalnych czy nawiązujących do rodzimych tradycji. Są wykonane w stylu klasycznym, z dobrych gatunków drewna. Ze względu na swoją znakomitą jakość, a także pochodzenie $\mathrm{z}$ importu, były w XIX w. obiektem dumy ich właścicieli. Meble są ustawione w taki sposób, by stworzyć wrażenie aranżacji oryginalnych wnętrz aptecznych, z pełnym wyposażeniem w szkło, wagi i inne utensylia wykorzystywane w praktyce przez pracowników aptek.

Pod względem aranżacji ekspozycja Muzeum Farmacji Wydziału Farmaceutycznego Uniwersytetu w Stambule przypomina muzea europejskie sprzed II wojny światowej, szczególnie te o niewielkiej przestrzeni ekspozycyjnej i pozbawione magazynów. Eksponatów w stambulskim Muzeum Farmacji jest bowiem bardzo dużo, zostały ciasno zgrupowane w przestrzeni wystawienniczej. Brak magazynów i dążenie do umieszczenia jak największej liczby zabytków na wystawie stałej ogranicza czytelność planu ekspozycji i utrudnia percepcję wszystkich prezentowanych obiektów w odpowiedniej perspektywie i kontekście. Zmniejszenie ogólnej liczby wystawianych eksponatów, wyodrębnienie wśród nich ekspozycji stałej, realizującej wyraźnie sprecyzowany scenariusz, oraz tych przeznaczonych do wystawiania podczas wystaw czasowych, mogłoby uczynić tę placówkę ciekawszą dla zwiedzających. Na pewno czytelność ekspozycji Muzeum Farmacji zapewniłoby jej przeniesienie do bardziej obszernego wnętrza, co umożliwiłoby rozdzielenie różnych rodzajów eksponatów według kryteriów tematycznych i opatrzenie ich np. tablicami informacyjnymi, uzupełniającymi kontekst historyczny prezentowanych zabytków.

W ogólnej ocenie ekspozycji Muzeum Farmacji Wydziału Farmaceutycznego należy podkreślić przede wszystkim historycznie cenny charakter zbiorów, a nie sposób ich zaaranżowania. Są to bowiem zbiory oryginalne, a nie ich zdjęcia lub kopie. Cel ekspozycji można uznać za odtworzony $\mathrm{w}$ planie wystawy w sposób wyraźny i prawidłowy. Wystawa ukazuje proces „europeizacji” farmacji tureckiej w XIX w., jej dostosowanie się do ówczesnych europejskich wzorców metodolo- 
gicznych i technologicznych nauk przyrodniczych. Dokumentuje też zaangażowanie wykładowców i studentów tureckich w ten proces.

Przyjrzyjmy się obecnie wybranym fragmentom ekspozycji stałej Muzeum Farmacji Wydziału Farmaceutycznego Uniwersytetu w Stambule. Wykonane przeze mnie fotografie umożliwią czytelnikowi zapoznanie się z treścią tej ekspozycji. Nie jest ona bowiem dostępna on-line. Muzeum nie wydało także dotąd przewodnika po swoich zbiorach.

Ekspozycja Muzeum Farmacji Uniwersytetu w Stambule wyraźnie odbiega swoją stylistyką od pozostałych wnętrz głównego kampusu tej uczelni, w których zostały wyraźnie wyeksponowane elementy nawiązujące do rodzimej tradycji historycznej. Przykładem zastosowanych tu rozwiązań może być brama główna do kampusu Uniwersytetu w Stambule, której projekt jest wyraźnie zbieżny pod względem stylistycznym z główną bramą do nowego pałacu sułtanów Dolmabahçe nad Bosforem, wybudowanego w początkach XIX w. Możemy w nim odnaleźć nawiązania do rodzimej tradycji architektury pałacowej, jak również do wzorców budownictwa rezydencjalnego o rodowodzie europejskim w stylu rokoko, ze szczególnym uwzględnieniem Wersalu. Budynek rektoratu i główne sale wykładowe Uniwersytetu w Stambule uwzględniają także orientalną stylistykę w aranżacji wnętrz. Ich ściany wyłożone są drewnianymi intarsjami o motywach kwiatowych (w tym szczególnie tulipanów) albo tkaninami o orientalnym wzornictwie. Całość dopełniają (podobnie jak w pałacu Dolmabahçe) klatki schodowe, podłogi i elementy ścian wykonane $\mathrm{z}$ marmuru oraz weneckie kryształowe lampy. We wnętrzach brak jest rzeźb z motywami figuralnymi oraz obrazów zawierających przedstawienia ludzkich i zwierzęcych postaci, jest to bowiem zakazane w islamie.

W tym kontekście budynek Wydziału Farmaceutycznego i jego wnętrza należy uznać za odbiegające od ogólnego standardu Uniwersytetu, a jego stylistykę możemy scharakteryzować jako pozostającą pod wpływem europejskich instytucji medycznych i farmaceutycznych. Może o tym świadczyć już hall budynku Wydziału, w którym znajdujemy trzy figuralne pomniki patronów medycyny - Hipokratesa, Galena i Awicenny. Ten sposób przedstawienia nie jest oczywisty w kulturze muzułmańskiej, zabraniającej wykonywania podobieństw postaci ludzkich, zwierząt i roślin. Jak widać, zakaz ten został w tym miejscu przełamany, podobnie jak w ilustracjach do podręczników do nauczania tych dziedzin, eksponowanych na wystawie w Muzeum Farmacji. Względy profesjonalne, umożliwiające przedstawienie ludzi 


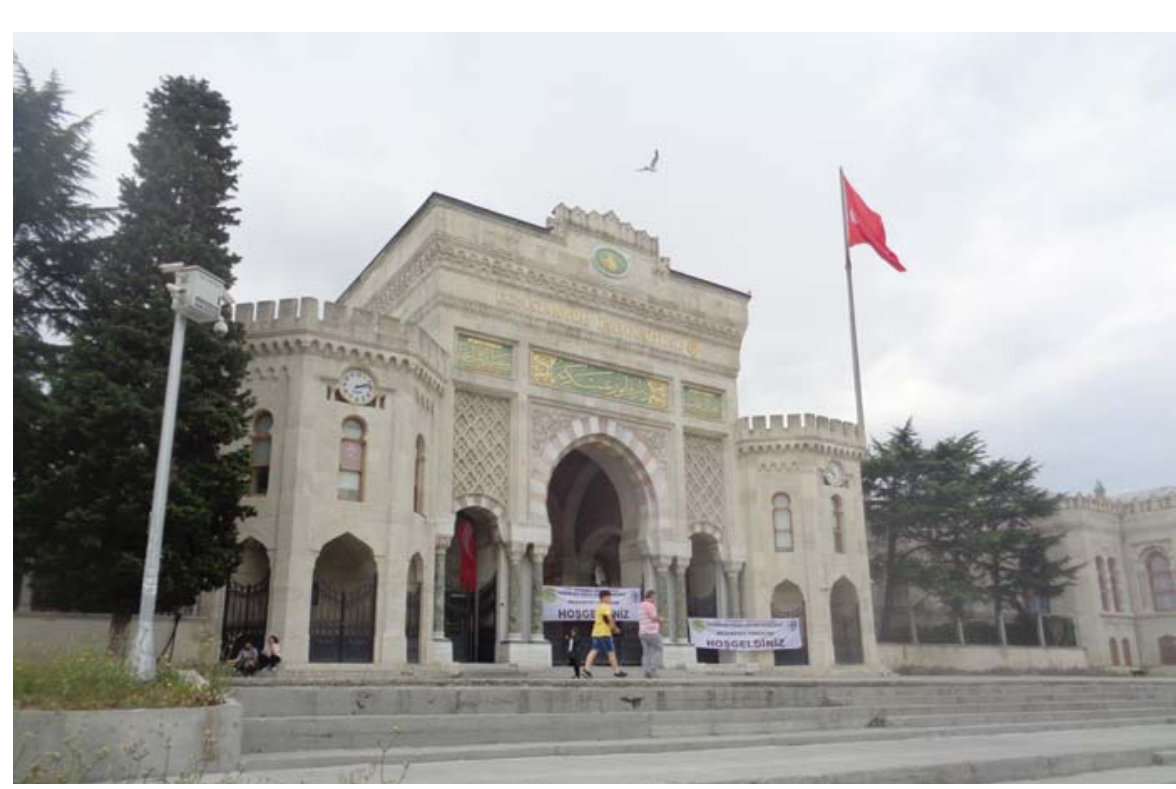

Fot. 1. Brama główna do kampusu Uniwersytetu w Stambule, założonego w 1453 r. w miejscu istniejącej tu wcześniej bizantyjskiej akademii Athenaeum

Źródło: Fot. B. Płonka-Syroka (2018).

i zwierząt, zostały dzięki temu uprawomocnione w sposób symboliczny. Ich wykonywanie zostało umotywowane względami dydaktycznymi. W hallu Wydziału Farmaceutycznego znajduje się także pamiątkowa tablica ku czci patrona europejskiej farmacji - Dioskoridesa, którego dorobek był wykorzystywany przez uczonych greckich, a następnie chrześcijańskich, jak i należących do islamskiego kręgu kulturowego. W ten sposób zostały podkreślone wspólne źródła nowożytnej farmacji europejskiej i tureckiej. Pomnik Awicenny, którego dzieła były w powszechnym użyciu w Europie Zachodniej do XVIII w., wskazuje zarazem na dwukierunkowy charakter recepcji standardu medycyny i farmacji. Przebiegała ona bowiem nie tylko z zachodu Europy na wschód, lecz także z krajów Orientu na zachód.

Wkraczając do Muzeum Farmacji Uniwersytetu w Stambule, znajdujemy się w świecie profesjonalnej farmacji XIX-wiecznej, o zachodnioeuropejskim rodowodzie. Wrażenie to stwarzają przede wszystkim zgromadzone tu i prezentowane meble apteczne. Wszystkie zostały wyprodukowane w Europie i sprowadzone do Turcji. Producentami tych mebli były profesjonalne firmy niemieckie, włoskie i szwajcar- 


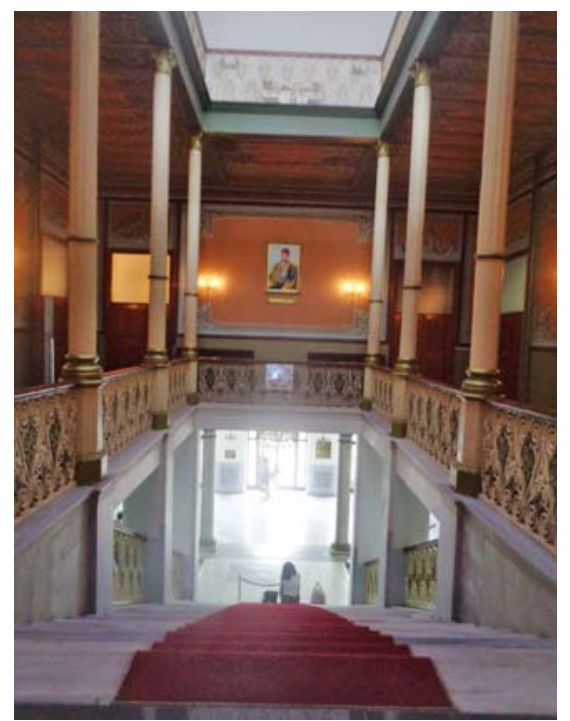

Fot. 2. Hall zabytkowego budynku Wydziału Farmaceutycznego Uniwersytetu w Stambule z 1839 r.

Źródło: Fot. B. Płonka-Syroka (2018). skie. Są utrzymane w nowoczesnej stylistyce, a zarazem eleganckie. Klient tureckiej apteki prowadzącej działalność według zachodnioeuropejskich wzorów powinien był odnieść wrażenie, że oferowane $\mathrm{w}$ niej produkty cechuje wysoki poziom profesjonalny, a jej ogólny klimat jest dostosowany do oczekiwań nabywców należących w XIX w. do grona tureckiej elity społecznej. Elegancję i profesjonalizm działającej $\mathrm{w}$ europejskim stylu apteki podkreślać miały wszystkie elementy jej wyposażenia, dostępne percepcji klientów. Muzeum przedstawia ich przykłady, w tym przede wszystkim kolekcję włoskich porcelanowych i szklanych naczyń aptecznych.

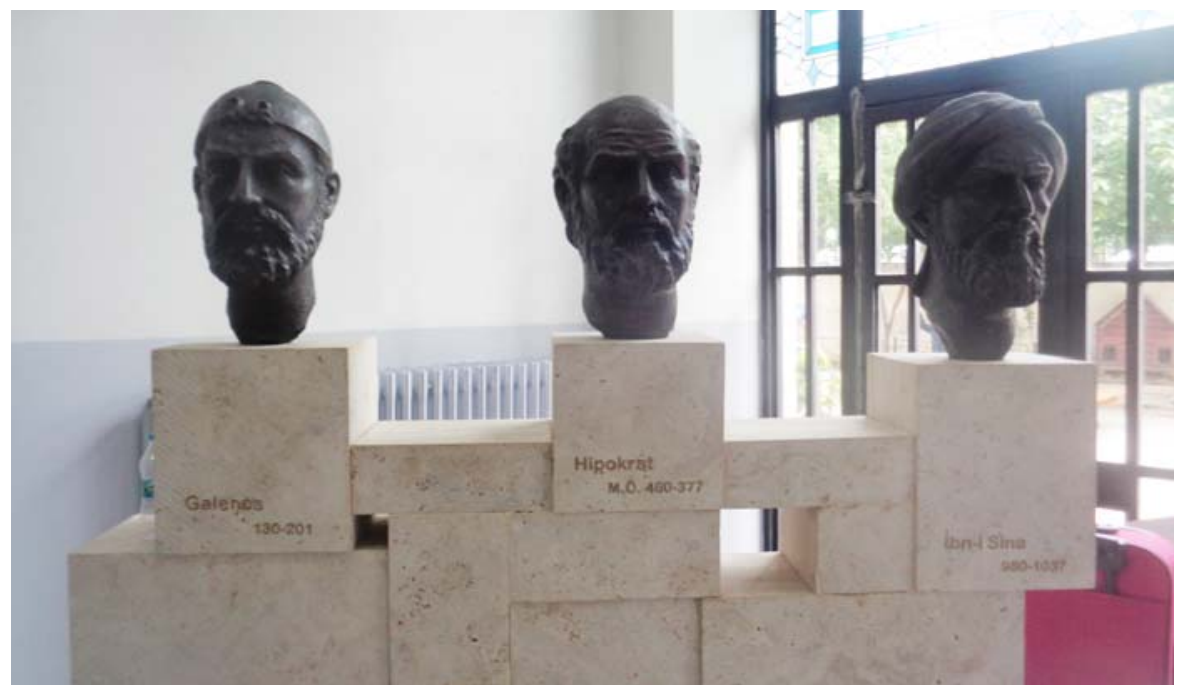

Fot. 3. Pomnik patronów medycyny i farmacji tureckiej - Hipokratesa, Galena i Awicenny - znajdujący się w hallu budynku Wydziału Farmaceutycznego Uniwersytetu w Stambule

Źródło: Fot. B. Płonka-Syroka (2018). 
Wybrane kolekcje historyczne z zakresu historii medycyny i farmacji...

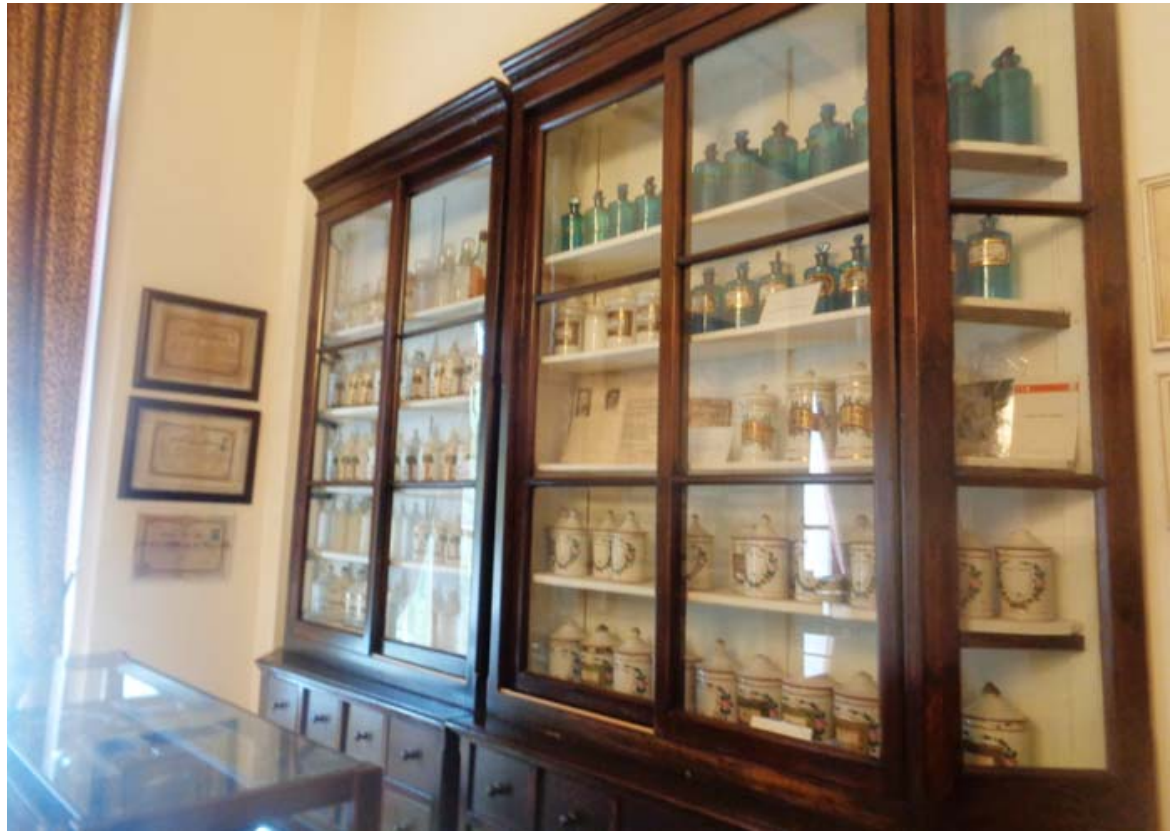

Fot. 4. Meble apteczne produkcji europejskiej z końca XIX w. Źródło: Fot. B. Płonka-Syroka (2018).

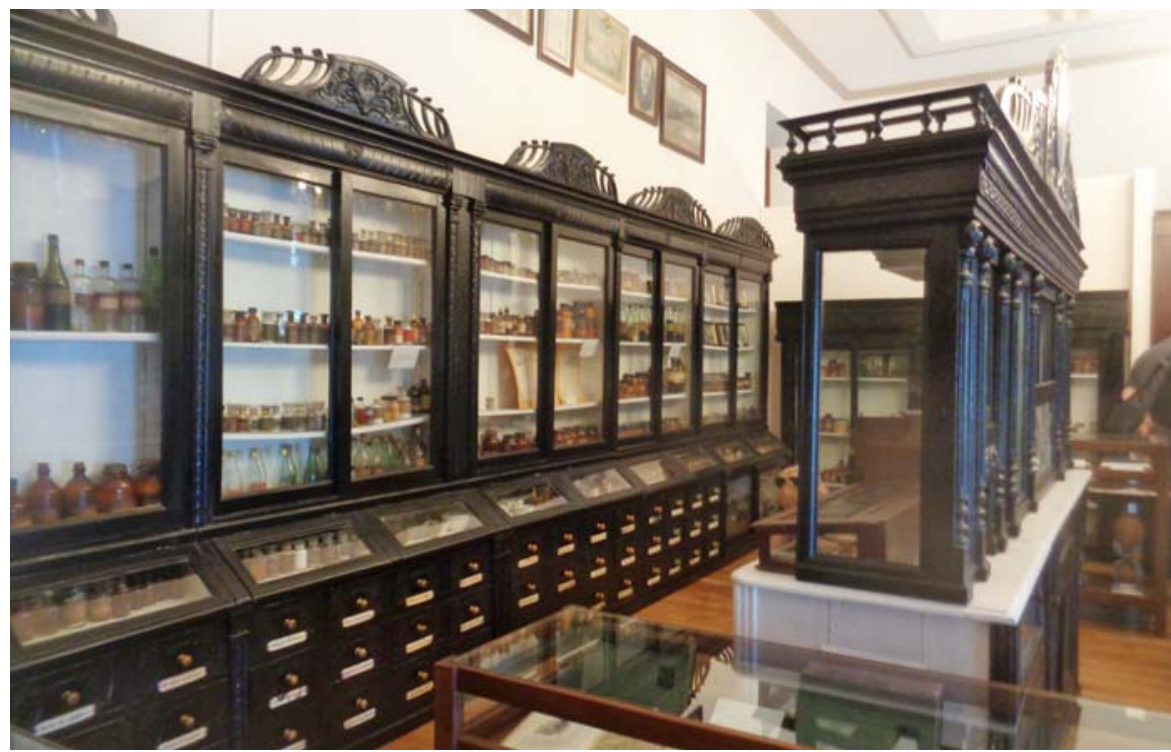

Fot. 5. Meble apteczne i wyposażenie apteki produkcji europejskiej (XIX w.) Źródło: Fot. B. Płonka-Syroka (2018). 


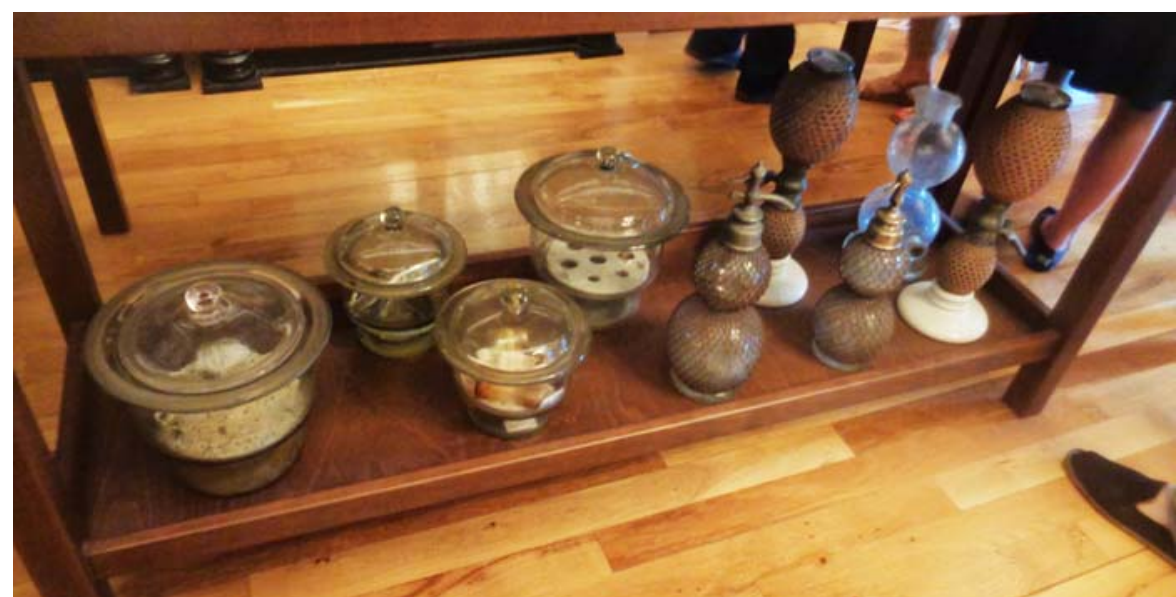

Fot. 6. Wyposażenie apteki - naczynia szklane i porcelanowe

Źródło: Fot. B. Płonka-Syroka (2018).

Muzeum Farmacji w Stambule przedstawia również przykłady wyposażenia wnętrz, które nie były dostępne dla klientów. Prezentowane jest zaplecze apteki: pomieszczenia do przechowywania surowców i wykonywania leków, lady apteczne, wagi, różne rodzaje sprzętów służących do produkcji leków aptecznych. Fragmentem ekspozycji jest także prywatne biuro aptekarza. Znajduje się w nim biurko, kasa, a także ważne dla poczucia samoidentyfikacji zawodowej dokumenty: dyplom ukończenia studiów czy zdjęcia absolwentów studiów farmaceutycznych. Obok znajduje się gablota mieszcząca różnego rodzaju nagrody uzyskiwane przez stambulskich studentów farmacji oraz przykłady dyplomów ukończenia studiów farmaceutycznych i zbiorowych zdjęć absolwentów. Muzeum dokumentuje w ten sposób kształtowanie się świadomości grupowej nowocześnie wykształconych według zachodnioeuropejskich wzorów tureckich farmaceutów, ich poczucie identyfikacji z zawodem, prywatne związki i studenckie przyjaźnie.

Ważnym fragmentem ekspozycji stałej Muzeum Farmacji są książki, pochodzące głównie z XIX w., kiedy to rozpoczął się proces przyspieszonej modernizacji medycyny i farmacji tureckiej. W kolekcji są jednak także książki wydane zarówno w XVIII (np. Farmakopea francuska z 1734 r.), jak i w XX w. (np. Farmakopea turecka z 1930 r.). Prezentacja w Muzeum Farmacji wielu książek, wydrukowanych w Europie Zachodniej, będących w XIX i 1 połowie XX w. podstawą nauczania $w$ Turcji farmacji i nauk pokrewnych (botaniki, farmako- 
Wybrane kolekcje historyczne z zakresu historii medycyny i farmacji...

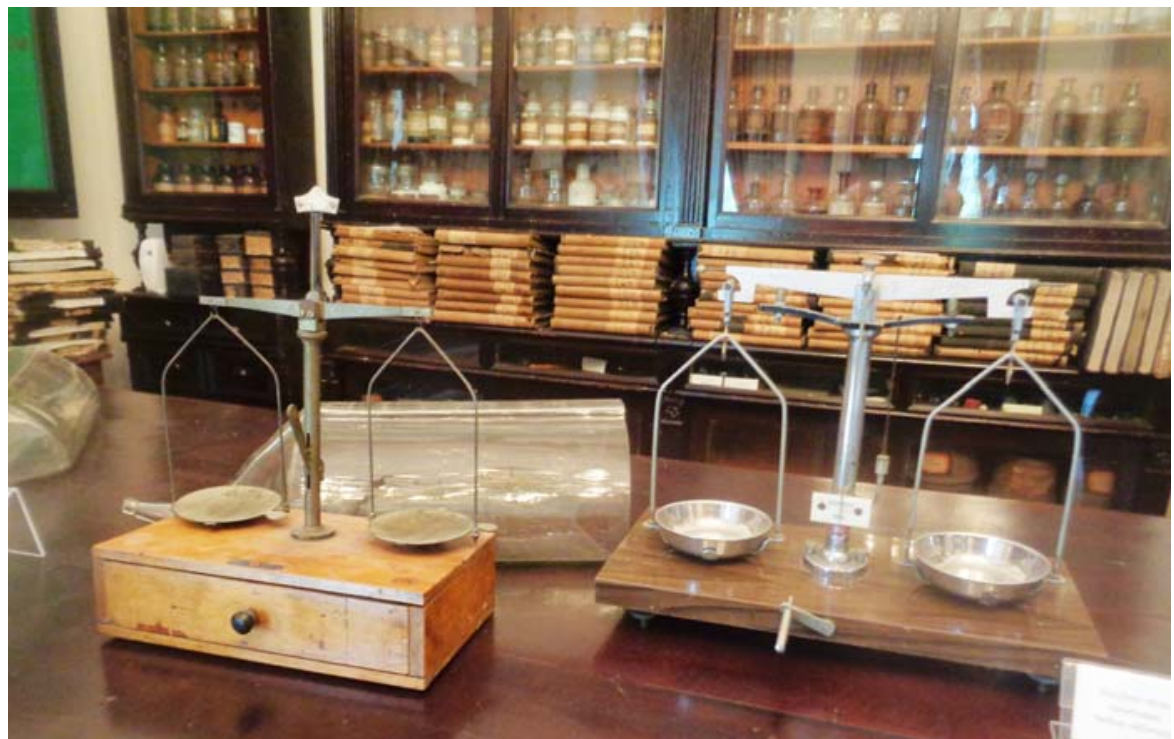

Fot. 7. Wnętrze apteki - lada apteczna, wagi, w tle podręczniki farmacji z XIX w.

Źródło: Fot. B. Płonka-Syroka (2018).

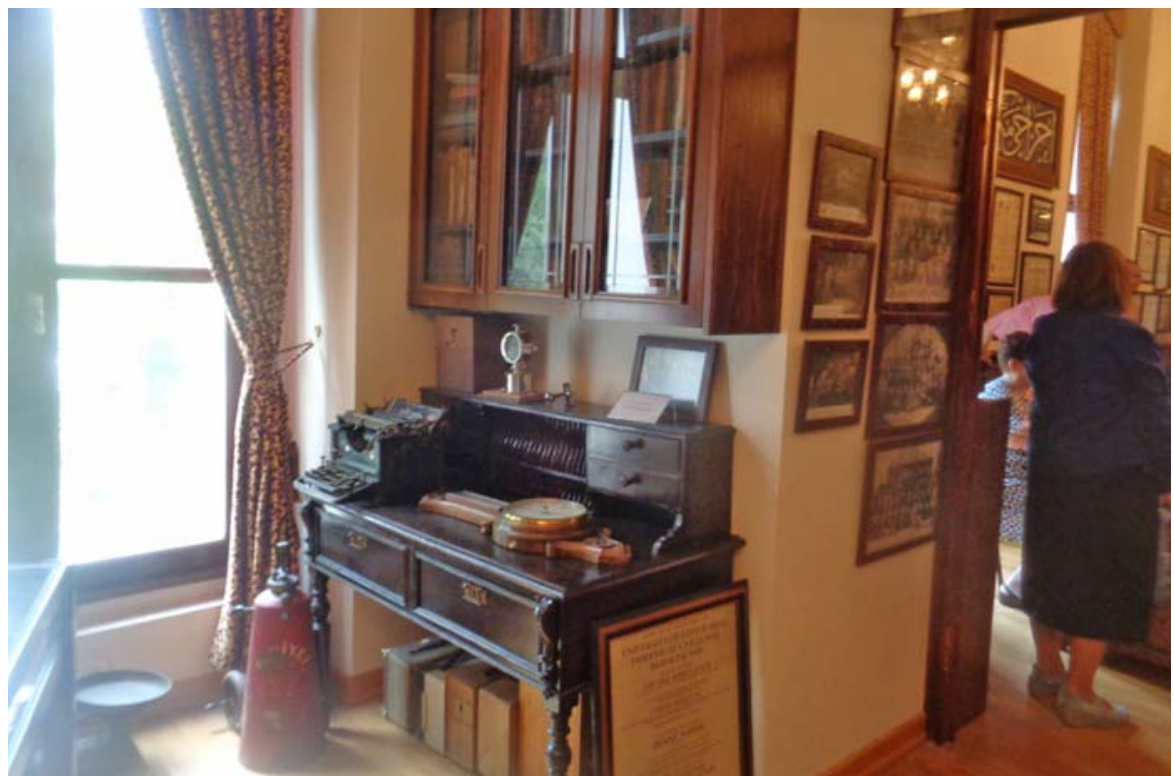

Fot. 8. Wnętrze apteki - prywatne biuro aptekarza, kasa, dyplom ukończenia studiów, zdjęcia absolwentów

Źródło: Fot. B. Płonka-Syroka (2018). 


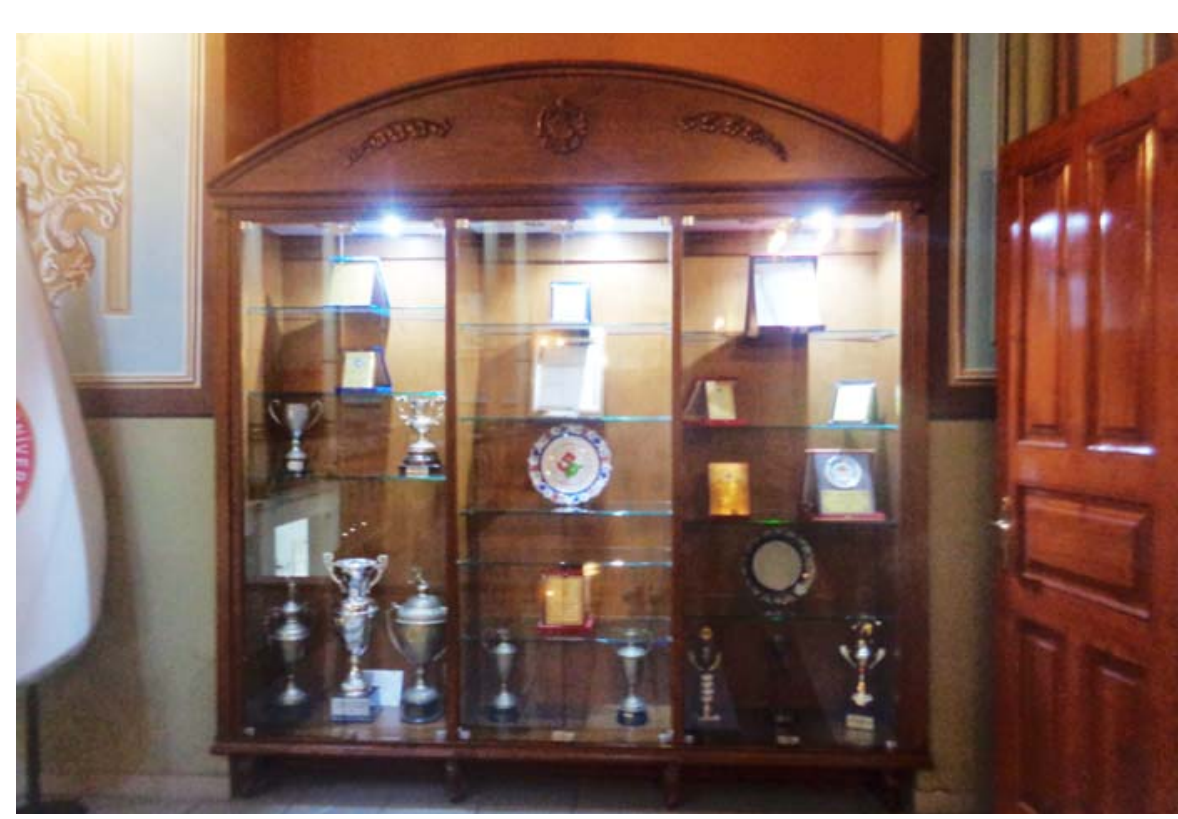

Fot. 9. Nagrody i dyplomy uzyskane przez studentów Wydziału Farmacji Uniwersytetu w Stambule w różnych konkursach

Źródło: Fot. B. Płonka-Syroka (2018).

gnozji, chemii), ma udokumentować proces modernizacji rodzimego tureckiego przyrodoznawstwa, nie tylko pod względem przekazywanych studentom merytorycznych treści, lecz także pod względem przełamywania barier edukacyjnych, wypływających z czynników światopoglądowych. Do końca XVIII w. edukacja tureckich studentów w dziedzinie medycyny i farmacji odbywała się bowiem na podstawie książek rękopiśmiennych, w których jedynym dopuszczalnym rodzajem ilustracji przedstawiających omawiane treści były wykonywane ręcznie przez profesjonalnych kopistów miniatury medyczne. $\mathrm{Na}$ ich podstawie kształcono się $\mathrm{w}$ zakresie anatomii i fizjologii, a także diagnostyki i terapii. W książkach rękopiśmiennych praktycznie nie występowały miniatury o treściach botanicznych. Schematyczny charakter tych ilustracji sprawiał, że musiały być one uzupełniane komentarzem wykładowcy. Zarówno ludzkie ciało, jak i wszystkie inne elementy nie były bowiem $\mathrm{w}$ tych miniaturach przedstawiane w sposób realistyczny ${ }^{14}$. W podręcznikach medycyny i farmacji, wy-

${ }^{14}$ Islamskie miniatury medyczne są dostępne dla polskiego odbiorcy w zbiorach Muzeum Farmacji Uniwersytetu Medycznego we Wrocławiu. Muzeum można zwiedzać on-line. Ich charakterystykę można znaleźć w artykule: B. Płonka-Syroka, Kolekcja 


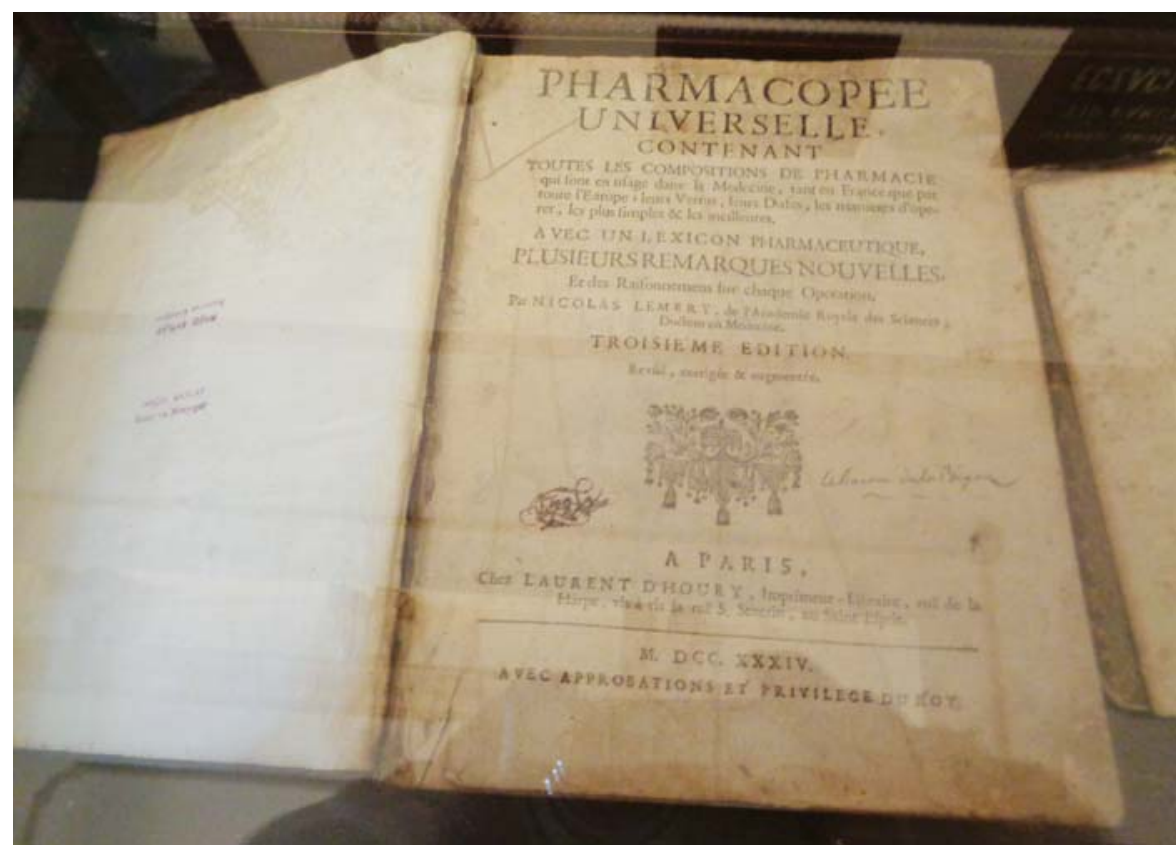

Fot. 10. Farmakopea francuska $\mathrm{z} 1734 \mathrm{r}$.

Źródło: Fot. B. Płonka-Syroka (2018).

dawanych w Europie i sprowadzanych do Turcji w XIX w., zamieszczane $\mathrm{w}$ nich ilustracje nie miały takich ograniczeń. Były nie tylko w pełni realistyczne, lecz także dokładne i drobiazgowe. Umożliwiało to studentom farmacji dokładne zapoznanie się z anatomią ludzkiego ciała, a także z budową roślin leczniczych. Sprowadzono do Turcji również podręczniki umożliwiające samodzielne zakładanie ogrodów roślin leczniczych, według pewnego ramowego planu uwzględniającego klasyfikację roślin. W kolekcji Muzeum Farmacji eksponowane są przykłady farmakopei z XVIII, XIX i XX w. i podręczniki do botaniki i farmakognozji. Zwiedzającym ukazuje się publikowane w nich realistyczne ilustracje, przełamujące obowiązującą dotąd w tureckiej edukacji uniwersyteckiej konwencję.

miniatur islamskich w zbiorach Muzeum Farmacji Uniwersytetu Medycznego im. Piastów Śląskich we Wrocławiu, [w:] A. Marek, B. Urbanek (red.), Rozwój aptekarstwa Śląskiego: moda i styl $w$ aptekach polskich ze szczególnym uwzględnieniem Ślaska, Śląski Uniwersytet Medyczny, Katowice 2014, s. 289-308. Jest to w polskich zbiorach muzealnych jedyna kolekcja tego typu. 


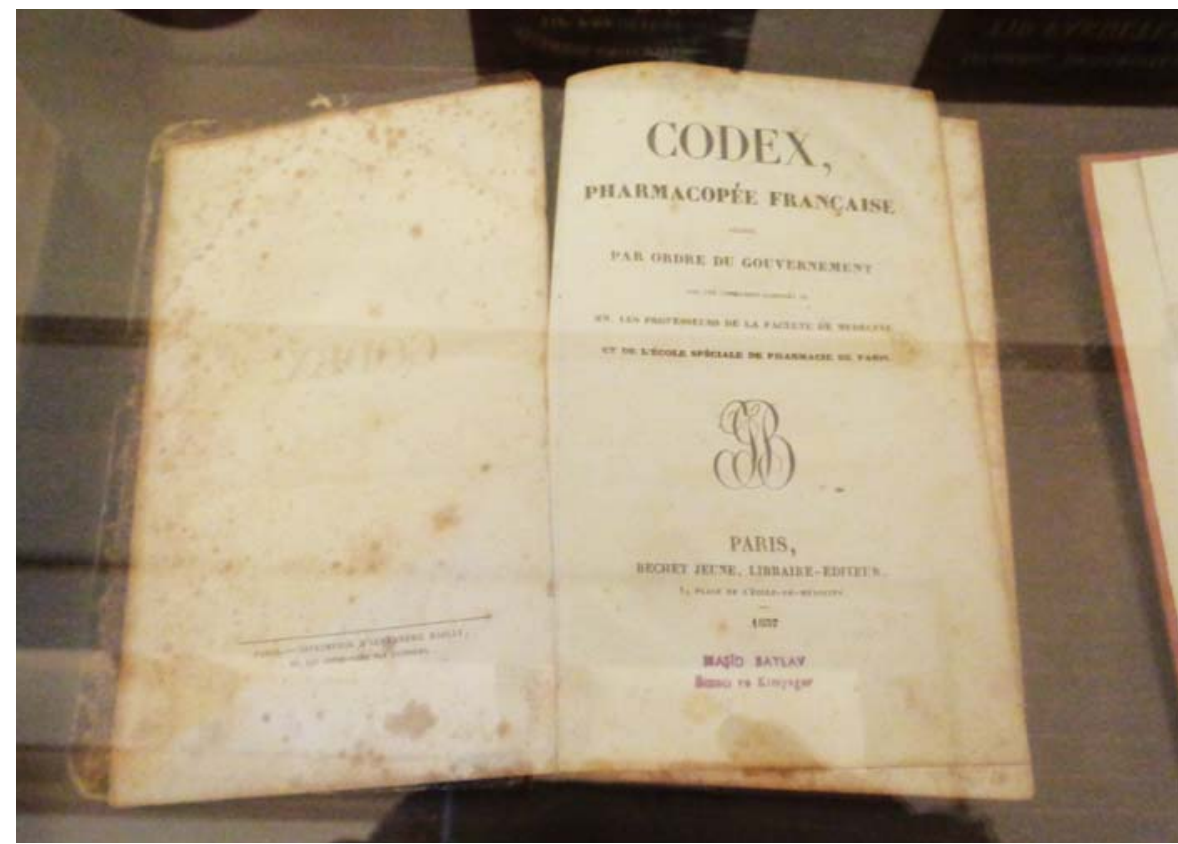

Fot. 11. Farmakopea francuska z XIX w.

Źródło: Fot. B. Płonka-Syroka (2018).

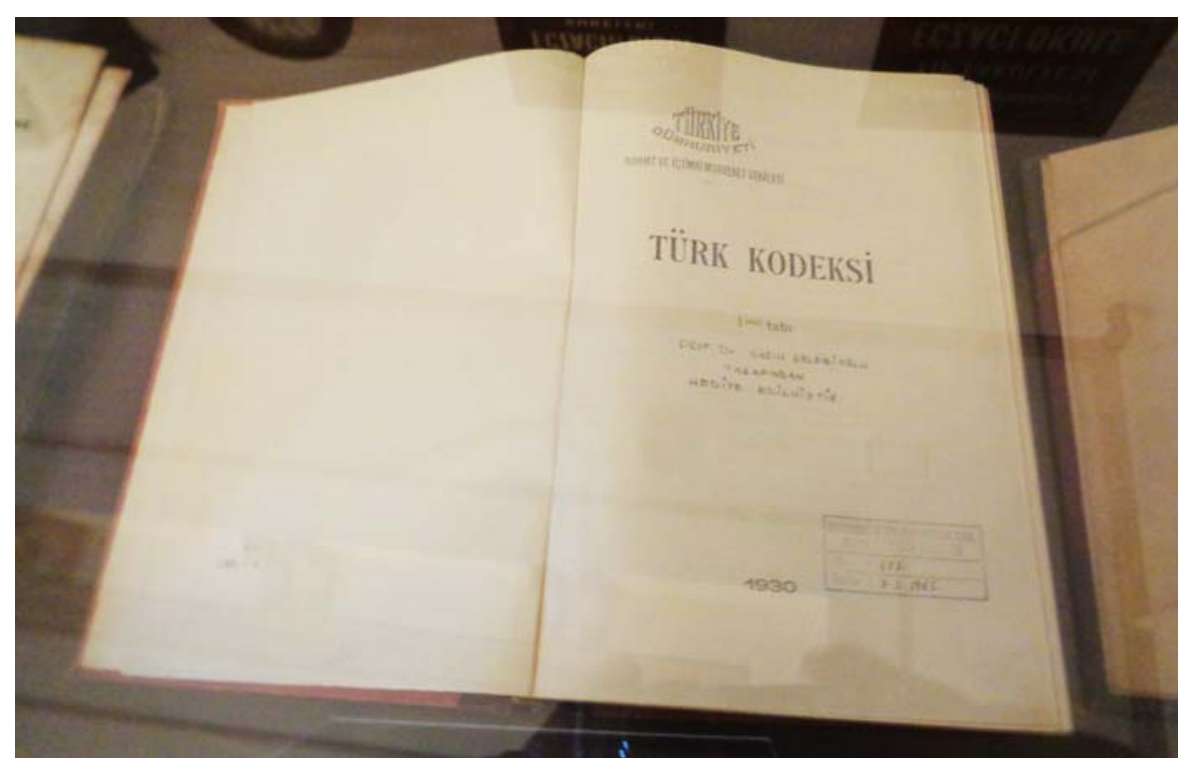

Fot. 12. Farmakopea turecka z 1930 r.

Źródło: Fot. B. Płonka-Syroka (2018). 
Wybrane kolekcje historyczne z zakresu historii medycyny i farmacji...

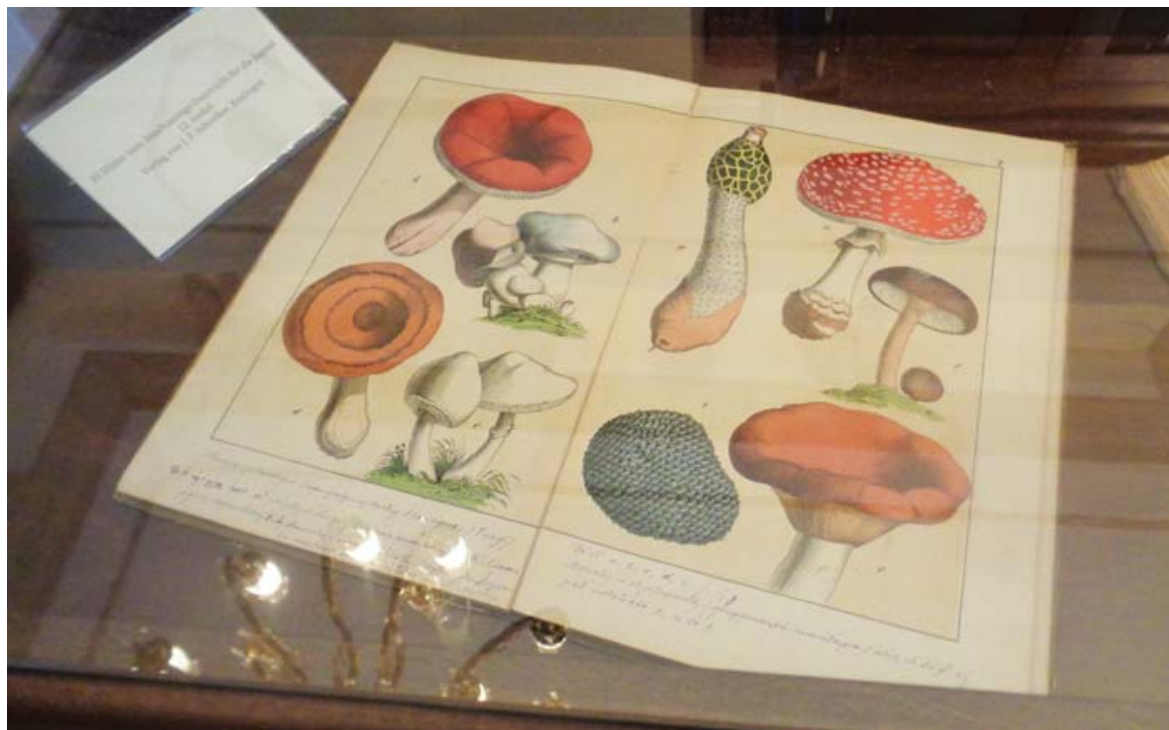

Fot. 13. Podręcznik botaniki wydany w XIX w. w Erlangen - jedna z ilustracji

Źródło: Fot. B. Płonka-Syroka (2018).

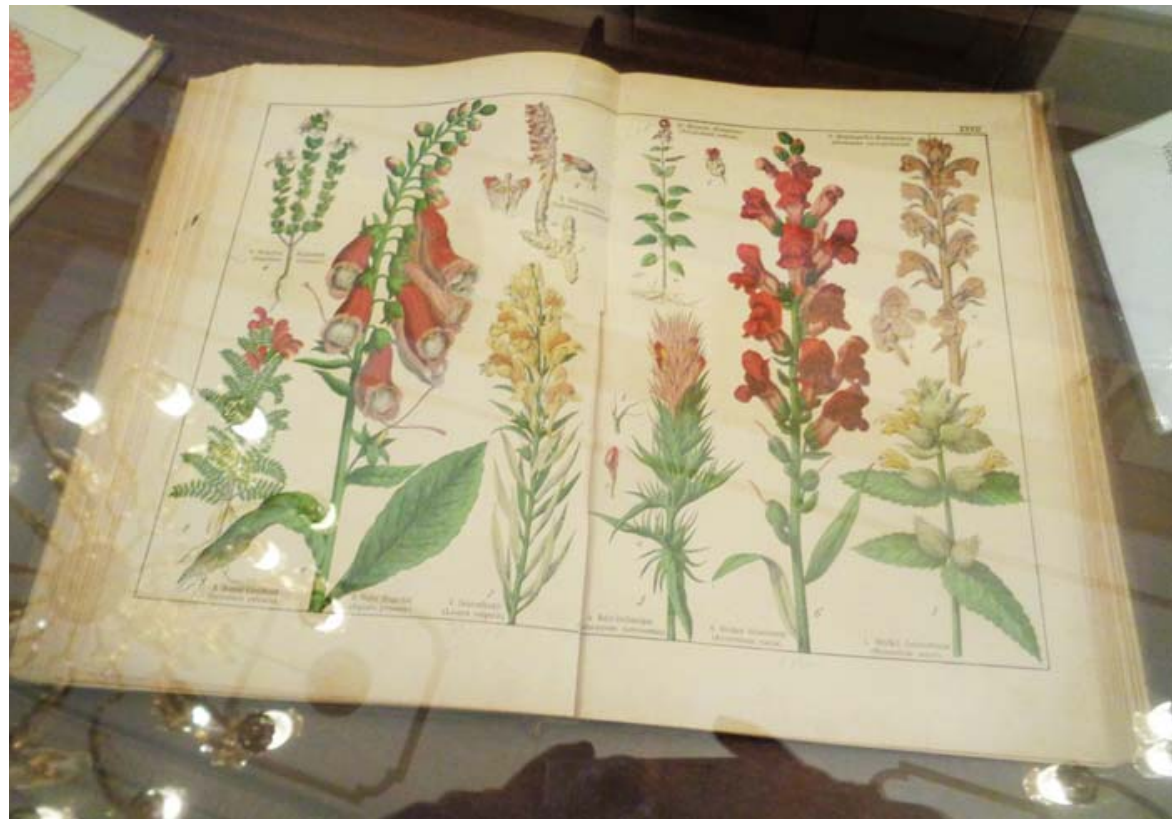

Fot. 14. Niemiecki podręcznik farmakognozji z XIX w. - jedna z ilustracji Źródło: Fot. B. Płonka-Syroka (2018). 


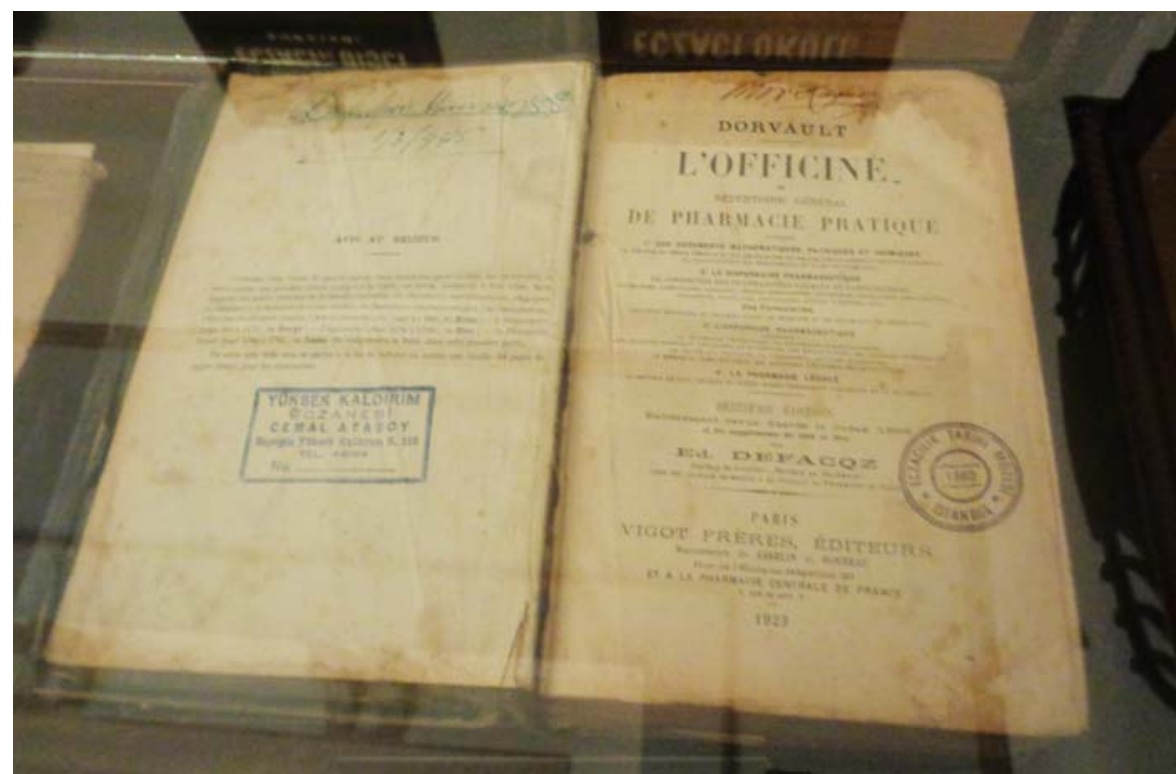

Fot. 15. Podręcznik farmacji praktycznej wydany w Paryżu w 1923 r.

Źródło: Fot. B. Płonka-Syroka (2018).

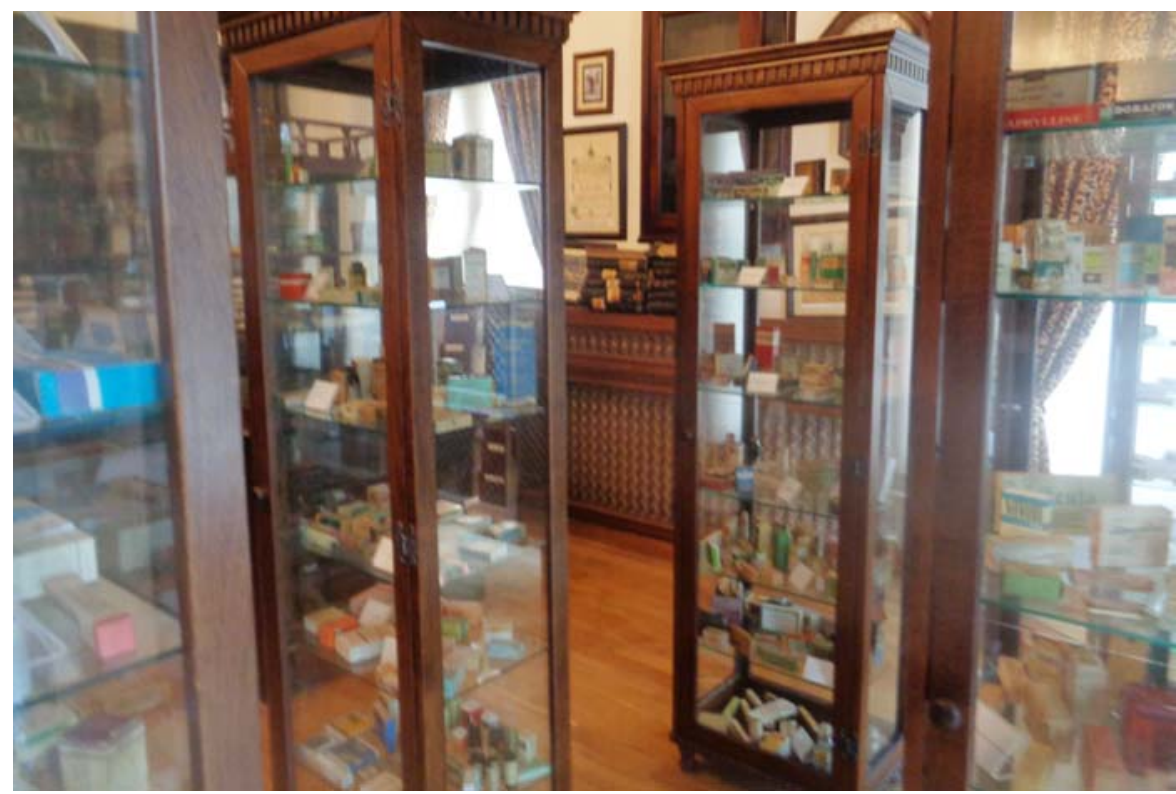

Fot. 16. Kolekcja tureckich leków aptecznych i produkowanych fabrycznie z końca XIX i pierwszej połowy XX w.

Źródło: Fot. B. Płonka-Syroka (2018). 
Następnym istotnym działem $\mathrm{w}$ ekspozycji stałej stambulskiego Muzeum Farmacji są przykłady produkowanych w Turcji leków. Ich wytwarzanie odbywa się według aktualnego europejskiego standardu, co potwierdza wystawiony francuski podręcznik farmacji praktycznej z $1923 \mathrm{r}$. W muzeum zostały przedstawione tureckie leki apteczne produkowane w XIX i w początkach XX w., jak i tureckie leki fabryczne, których produkcję rozpoczęto w końcu XIX w. Ekspozycja ta dokumentuje początkowy etap współczesnego tureckiego przemysłu farmaceutycznego, który obecnie przynosi Turcji spory procent dochodów PKB.

Przedstawiony tu przegląd zbiorów stambulskiego Muzeum Farmacji ukazuje zgodność planu wystawy oraz celu, który był podstawą jego sformułowania. Muzeum spełnia też inny, ważny warunek: przedstawia przede wszystkim oryginalne eksponaty z epoki, której wystawa dotyczy. Eksponaty te mają dużą wartość historyczną. Dokumentują nie tylko rozwój rodzimej farmacji w Turcji, ale wkład zachodnioeuropejskiego standardu farmacji do stworzenia tureckiego standardu farmacji akademickiej. Warto przypomnieć w tym kontekście, że na uniwersytetach europejskich samodzielne wydziały farmacji zaczęły powstawać na przełomie XVIII i XIX w. (wcześniej nauczano farmacji w systemie cechowym). Tworzenie wydziałów farmacji w Imperium Osmańskim rozpoczęło się niespełna cztery dekady później, co świadczy o nadążaniu przez tamtejsze środowisko uniwersyteckie za tendencjami w standardzie nauczania nauk przyrodniczych.

Według tych samych założeń, co wyżej przedstawione, zostało skonstruowane Muzeum Farmacji Wydziału Farmaceutycznego Uniwersytetu Anadolu (Anadolu University) w Stambule ${ }^{15}$. Świadczy to o tym, że w tureckiej praktyce wystawienniczej omówiony powyżej standard należy uznać za uniwersalny. Muzeum Farmacji Uniwersytetu Anadolu jest mniejsze niż należące do Uniwersytetu Stambulskiego. Składa się z jednego pomieszczenia, w którym zostało pieczołowicie odtworzone historyczne wnętrze apteki według standardu obowiązującego w Europie w 2 połowie XIX w. W kolekcji znajdują się meble apteczne, urządzenia do produkcji leków aptecznych, wagi, naczynia porcelanowe, szklane i metalowe, odważniki, opakowania leków. Ze względu na możliwość obejrzenia tego muzeum w Internecie nie będę szerzej charakteryzowała jego zbiorów.

${ }^{15}$ Y. Öztürk, A Virtual Historical Museum: the Cals of Historical Sihhat Pharmacy (Tarihi Sihat Eczanesi) in the Faculty of Anadolu University, [w:] A. Mat, H. Tekiner, B. Sen (red.), op. cit., s. 385-389. 


\section{Muzeum Historii Medycyny i Farmacji Uniwersytetu w Stambule}

Drugie muzeum, w którym znajdują się eksponaty o tematyce farmaceutycznej, istnieje w strukturze Wydziału Lekarskiego Uniwersytetu w Stambule. Jest to Muzeum Historii Medycyny i Farmacji ${ }^{16}$, w którym obie te dziedziny nauki wzajemnie ze sobą korespondują. Muzeum mieści się $\mathrm{w}$ jednym $\mathrm{z}$ budynków dydaktycznych Wydziału Lekarskiego, zbudowanych w 1 połowie XX w., położonych w odległości kilku przystanków tramwajowych od centralnego kampusu uczelni. Ekspozycja Muzeum Historii Medycyny i Farmacji Uniwersytetu w Stambule także ma wyraźny plan, odzwierciedlający ogólny cel wystawy. Jest nim przedstawienie procesu kształtowania się tureckiej medycyny klinicznej w XIX stuleciu, z uwzględnieniem najważniejszych etapów jej historii. W Muzeum prezentowana jest ekspozycja stała. Ponieważ na cele muzealne została udostępniona znacznie większa powierzchnia wystawiennicza niż w Muzeum Farmacji, możliwe było zgrupowanie eksponatów pod względem tematycznym i przedstawienie kształtowania się standardu tureckiej medycyny w porządku chronologicznym. Realizację tego zamierzenia należy uznać za udaną i czytelną.

W pierwszej sali ekspozycyjnej, znajdującej się tuż przy wejściu, zostały udokumentowane początki tureckiej historii medycyny i farmacji, które mają dwa źródła: standard medycyny greckiej (i jej kontynuacji w Rzymie i Bizancjum) i jego średniowieczną recepcję w kręgu nauki islamskiej. W sali zostały zaprezentowane ręcznie malowane miniatury medyczne ${ }^{17}$, które są doskonałą ilustracją komplementarności obu tych źródeł. Miniatury malowane są bowiem w oryginalnej, charakterystycznej dla islamskiego kręgu kulturowego konwencji stylistycznej, niezmieniającej się od XII aż do końca XVIII w. i niewystępującej w artystycznym malarstwie europejskim. Miniatury, będące ilustracjami do dzieł Hipokratesa, Galena, innych klasyków starożytnych oraz rodzimych autorów islamskich, umożliwiają zwiedzającym zapoznanie się z klasycznym standardem greckiej patologii humoralnej, który był teoretyczną podstawą także rozwijających ów standard we własnych dziełach autorów z kręgu islamskiego. W treści tych mi-

${ }^{16}$ F. Erbay, op. cit.

${ }^{17}$ Charakterystykę tego typu źródeł obszernie przedstawiam w artykule pt. Medycyna islamska w świetle średniowiecznych miniatur medycznych, [w:] B. Płonka-Syroka, Ł. Braun (red.), Kultura medyczna islamu, Wydawnictwo DiG, Warszawa 2015, s. 17-56. 
niatur zostały jednak - obok greckich - uwidocznione także inne wpływy, np. indyjskie i chińskie, przeniesione do medycyny islamskiej za pośrednictwem państw położonych wzdłuż jedwabnego szlaku.

W następnej, obszernej sali znajduje się ekspozycja poświęcona medycynie starożytnej Grecji, która dla późniejszych autorów arabskich stała się głównym źródłem inspiracji. W gablotach zostały wyeksponowane popiersia klasyków medycyny, Hipokratesa i Galena, wybrane przykłady narzędzi chirurgicznych, kopie dzieł autorów greckich itp. W dalszej części ekspozycji przechodzimy przez kolejne epoki, przedstawiane jednak w sposób dość skrótowy, aż do początków XIX w., kiedy to $\mathrm{w}$ Turcji zaczyna się recepcja europejskiego standardu medycyny klinicznej i powiązanego z nią standardu farmacji. Współczesny standard tych dziedzin, wspólny dla medycyny tureckiej i zachodnioeuropejskiej, jest przedstawiany jako „punkt dojścia”, który obie te nauki osiągnęły we względnie zbliżonym czasie. Europa Zachodnia ok. 1750 r., a nauka turecka - ok. 1830 r. Od tego czasu rozwijają się w sposób równoległy i komplementarny względem siebie.

W omawianym muzeum znajdziemy wiele przykładów uwzględniających wkład uczonych europejskich do modernizacji tureckiego przyrodoznawstwa. W ekspozycji znajdują się także przykłady wybitnych uczonych związanych z rodzimym kręgiem kulturowym. Obok importowanych książek i sprzętów pochodzących z XIX w., np. szkieł aptecznych, wag laboratoryjnych, odważników czy naczyń, znajdują się na wystawie stałej także liczne eksponaty o rodzimym rodowodzie. Wiele $\mathrm{z}$ nich zostało przekazanych do muzeum w latach 70 . XX w., gdy uczelnia stambulska została poddana modernizacji, z czym wiązało się wyposażenie wielu katedr w nowe meble i innego rodzaju sprzęty.

Ogólna charakterystyka wystawy może na pierwszy rzut oka sprowadzać się do stwierdzenia, że mamy do czynienia z ekspozycją dotycząca „historii medycyny i farmacji europejskiej w Turcji”. Wiele wystawianych w muzeum książek zostało bowiem wydanych w językach niemieckim, francuskim lub angielskim, a meble i sprzęty apteczne zostały wyprodukowane w Europie. Jedynym elementem „orientalnym" są miniatury o tematyce medycznej i farmaceutycznej, zgromadzone w pierwszej sali Muzeum. W takiej charakterystyce ekspozycji muzealnej znajdują jednak wyraz nasze oczekiwania jako zwiedzających, wynikające z postrzegania nauki tureckiej przez okulary orientalizmu. Szukamy wśród muzealnych zabytków związanych z turecką historią medycyny i farmacji inności czy egzotyki, podczas gdy zasadnicza oś ekspozycji, jej cel i plan, odzwierciedlają zupełnie inne zało- 
żenie, przyjmowane przez twórców wystawy: wykazanie tożsamości europejskiego i tureckiego standardu klinicznego, wyprowadzanego ze wspólnych starożytnych wzorców i podlegającego ewolucji i modernizacji w stałym wzajemnym kontakcie, odbywającym się na przestrzeni wieków. Samoświadomość członków tureckiego środowiska lekarskiego już w XIX stuleciu można określić jako „kliniczną”, tworzącą się w kontakcie ze środowiskiem akademickim Wiednia, Berlina czy Paryża, a nie ze środowiskiem rodzimych terapeutów praktykujących zgodnie ze standardem „medycyny proroka”, o rodowodzie ludowym.

\section{Muzeum Hammamu Uniwersytetu w Stambule}

Ostatnim z muzeów Stambułu, które chciałabym przedstawić w tym artykule, jest Muzeum Hammamu Uniwersytetu w Stambule. Zostało utworzone w 2018 r. Jest zlokalizowane w odrestaurowanym dzięki państwowym dotacjom i środkom sponsorskim oryginalnym budynku hammamu, służącego wcześniej nie tylko celom kąpielowym i rekreacyjnym, lecz także leczniczym i kulturalnym. Muzeum jest położone tuż przy głównym kampusie Uniwersytetu Stambulskiego, kilkaset metrów od głównego wejścia do rektoratu. Ekspozycja Muzeum została oparta na tych samych założeniach, które są podstawą tureckiego standardu historii nauki i techniki, podkreślającego związek jego korzeni ze standardem starożytnej nauki greckiej i rzymskiej, która następnie była rozwijana $\mathrm{w}$ islamskim kręgu kulturowym ${ }^{18}$. Muzeum jest szeroko dostępne dla zwiedzających, zarówno z przewodnikiem (po wcześniejszym umówieniu się za pośrednictwem Internetu, także w językach angielskim i niemieckim), jak i dla gości indywidualnych.

${ }^{18}$ E. Alkan, Current Reflections of the Turkish Bath Culture, [w:] A. Namal, A.D. Erdemir, B. Płonka-Syroka (red.), Tarihte Saglik ve su Kültürü / Gesundheit und Wasserkultur in der Geschichte / Health and Water-Culture in History, Istanbul Medical Saglik ve Yayincilik Hiz. Tic. Ltd., Istanbul 2016, s. 211-2018; G.G. Cantay, Hammam Thermal Spring (Terms, Architecture, Bathing, Healing), [w:] A. Namal, A.D. Erdemir, B. Płonka-Syroka (red.), op. cit., s. 53-72; E. Gültekin, Geschichte der modernen Hydrotherapie in der Türkey mit einigen originalen Beiträgen, [w:] A. Namal, A.D. Erdemir, B. Płonka-Syroka (red.), op. cit., s. 15-26; D. Baran, Turkish Baths in the Romanian Principalities, [w:] A.D. Erdemir, S. Erer, Ö. Usmanbas, B. Akgün (red.), op.cit., s. 311320; A. Namal, Turkish bath in history and their place in daily life, [w:] B. Płonka-Syroka, A. Kaźmierczak, S. Jandziś, A. Syroka (red.), Tradycje i perspektywy rozwoju kultury uzdrowiskowej w Iwoniczu-Zdroju w kontekście europejskim, Kultura uzdrowiskowa w Europie, t. 10, Oficyna Wydawnicza Arboretum, Wrocław 2018, s. 121-133; N. Sari, Hydrotherapy as decripted in Ottoman Medical Manuscripts, [w:] A. Namal, A.D. Erdemir, B. Płonka-Syroka (red.), Saglik ve Su Kültürü / Gesundheit und Wasserkultur / Health and Water-Culture, Birinci Baski, Istanbul 2014, s. 161-169. 
Wybrane kolekcje historyczne z zakresu historii medycyny i farmacji...

Przedstawienie ekspozycji muzealnej zostanie przeprowadzone na podstawie wykonanych przeze mnie zdjęć. Muzeum nie jest bowiem na razie dostępne on-line. Nie wydano także jak dotąd przewodnika. Orientację $\mathrm{w}$ problematyce korzystania $\mathrm{z}$ hammamu może zapewnić polskiemu czytelnikowi przedstawione powyżej w przypisie piśmiennictwo. Niektóre z prac na ten temat zostały wydane w Polsce lub są dostępne (można uzyskać ich kopie) w Zakładzie Humanistycznych Nauk Farmaceutycznych Studium Nauk Humanistycznych i Społecznych Uniwersytetu Medycznego im. Piastów Śląskich we Wrocławiu.

Budynki tureckich hammanów wykonywane były z kamienia albo z cegły. Charakteryzowała je specyficzna architektura, której cechą była obecność kilku lub kilkunastu kopuł wznoszących się nad jednopiętrowym na ogół, długim i pozbawionym okien w zewnętrznych ścianach gmachem. Pod kopułami znajdowały się sale do kąpieli parowych, do których światło docierało jedynie z małych przeszklonych okienek umieszczonych w suficie. Sale do kąpieli parowych umieszczane były na końcu wewnętrznych traktów komunikacyjnych, od których były oddzielane drzwiami. Umożliwiało to uzyskanie w nich wysokiej temperatury pary wodnej. Pozostałe pomieszczenia hamma$\mathrm{mu}$ były umieszczane $\mathrm{w}$ amfiladzie. Użytkownicy przechodzili $\mathrm{z}$ jednego do drugiego, według ściśle określonego scenariusza korzystania z tego typu przybytków.

Regularne korzystanie z hammamu miało uzasadnienie nie tylko higieniczne (usunięcie ze skóry różnego rodzaju zanieczyszczeń), lecz także zdrowotne. Kontakt owiniętego jedynie w bawełniane lub lniane prześcieradło ciała $\mathrm{z}$ gorącą parą wodną uznawany był za sprzyjający zdrowiu i mający istotne znaczenie profilaktyczne. Zgodnie z systemem patologii humoralnej, który był podstawą oficjalnego systemu medycyny w Turcji, rozgrzanie ciała powodowało przyspieszenie krążenia humorów. Umożliwiało także wydalenie wraz z obficie wydzielającym się podczas tego zabiegu potem nadmiaru humorów oraz humorów skażonych. Po gorącym zabiegu parowym klient hammamu miał spędzić jeszcze jakiś czas w obrębie jego zabudowań, aby przywrócić krążenie humorów do normalnego poziomu.

W rozkładzie tureckiego hammamu znajdowały się elementy wspólne z prototypem tego urządzenia kąpielowego - termami z czasów rzymskich ${ }^{19}$. Najważniejszym z nich było budowanie specjalnych

${ }_{19}$ Por. M. Wolny, Wiedza medyczna w starożytnym Rzymie (III w. p.n.e. - I w. n.e.) jako podłoże kultury uzdrowiskowej w Imperium Romanum, [w:] B. Płonka-Syroka, A. Kaźmierczak (red.), Historia kultury uzdrowiskowej w Europie, t. 1, Oficyna Wydawnicza Arboretum, Wrocław 2012, s. 15-37; P.R. Szymański, Termy, między sacrum 


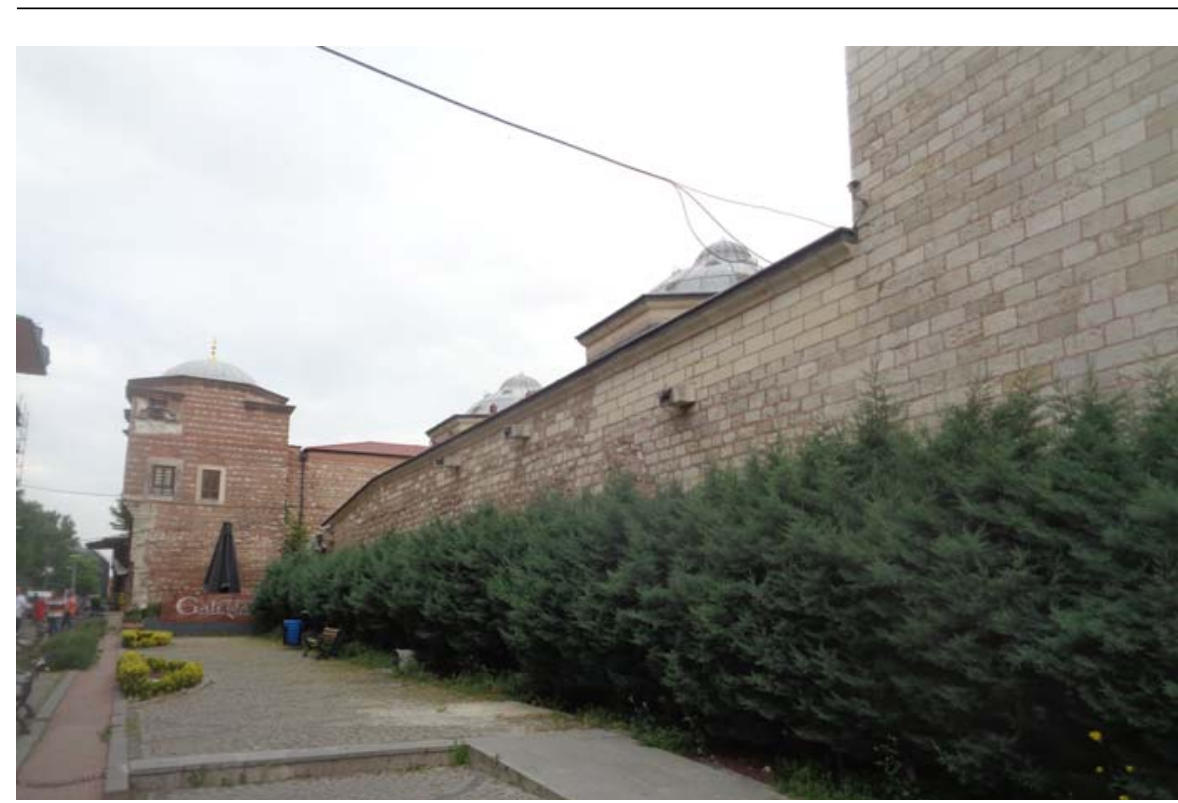

Fot. 17. Budynek Muzeum Hammamu Uniwersytetu w Stambule Źródło: Fot. B. Płonka-Syroka (2018).

budynków kąpielowych, umożliwiających klientom korzystanie z różnych form ablucji, a także ogólny plan tego typu zabiegów, stopniujących poziom natężenia bodźców termicznych, na które było w ich trakcie wystawiane ludzie ciało. Zabiegi rozpoczynały się od kontaktu z wodą o neutralnej temperaturze, która w kolejnych pomieszczeniach stopniowo wzrastała, aby po pewnym czasie zapewnić klientowi wpływ gorąca na odsłoniętą skórę. Czas pobytu klienta w wysokiej temperaturze był dostosowany do jego ogólnej kondycji. Po zabiegach gorących, mokrych i suchych klienci rzymskich term przenosili się do pomieszczań, w których panowała coraz niższa temperatura. Mogli korzystać z basenów z ciepłą wodą (płynącą z naturalnych źródeł lub podgrzewaną sztucznie, za pomocą systemu zwanego hypocaustum), a także basenów z wodą zimną. Zabiegi wodne kończył odpoczynek w specjalnych pomieszczeniach, w których klient miał możliwość obcowania z dobrami kultury: oglądania różnego rodzaju przedstawień z udziałem śpiewaków lub aktorów, kontemplowania dzieł sztuki,

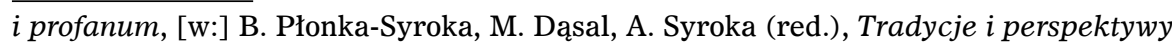
rozwoju kultury uzdrowiskowej w Województwie Świętokrzyskim w kontekście europejskim, Kultura uzdrowiskowa w Europie, t. 7, Oficyna Wydawnicza Arboretum, Wrocław 2016, s. 469-477. 
czytania manuskryptów. Mógł także zakończyć zabieg kolacją, której standard był dostosowany do jego statusu społecznego i finansowych możliwości.

W tureckich hammamach powyżej przedstawiony scenariusz uległ pewnym modyfikacjom, zakorzenionym zarówno $\mathrm{w}$ lokalnych poglądach lekarzy, jak i w rodzimej kulturze. Przede wszystkim nie było $\mathrm{w}$ hammamach typowych dla rzymskich term basenów z wodą stojącą - ani otwartych, ani krytych. W medycynie islamskiego kręgu kulturowego korzystania $\mathrm{z}$ kąpieli $\mathrm{w}$ wodach stojących nie uważano bowiem za zdrowe. Korzystano w związku z tym jedynie z kąpieli morskich lub rzecznych, a bardzo rzadko ze sztucznie utworzonych basenów - tylko wtedy, gdy były zapełniane przez wodę płynącą z naturalnych źródeł, o dużym natężeniu przepływu. Zapewniało to, że woda była stale wymieniana. Ze względu na rzadkie występowanie tego typu wydajnych źródeł oraz fakt, że większość hammamów budowano w miastach (w których przeważnie takie źródła nie występowały), baseny kąpielowe zniknęły z planu zabudowy hammamów. Lekarze islamscy zalecali - zamiast kąpieli w basenach czy wannach z wodą stojącą - gorące kąpiele parowe, obfite polewanie ciała (ciepłą, letnią lub zimną wodą) przy użyciu specjalnych naczyń (glinianych lub metalowych), a także dokładne obmywanie skóry przy użyciu niewielkich, lnianych lub bawełnianych ręczników. Możliwe było także (i zalecane jako zdrowe) korzystanie $\mathrm{w}$ hammamach $\mathrm{z}$ wody bieżącej, płynącej z kranów umieszczonych $\mathrm{w}$ ścianach albo $\mathrm{z}$ fontann.

Drugą cechą różniącą rzymskie termy od ich tureckiego odpowiednika było to, że zarówno w Rzymie, jak i w Bizancjum z zabiegów w publicznych termach wspólnie korzystali klienci obojga płci. O ile dla mężczyzn korzystanie to przebiegało bez żadnych ograniczeń (poza związanymi z ich statusem społecznym: zamożniejsi klienci kąpali się rano, kiedy woda w basenach była czysta, a biedni po południu i wieczorem, kiedy nie była już tak świeża, ale zabiegi były wówczas tańsze), o tyle kobiety korzystające nago z basenów w publicznych termach rzymskich wywodziły się przeważne z niższych warstw społecznych lub z grona niewolnic i prostytutek. Ich obecność w termach miała uzasadnienie przede wszystkim $\mathrm{w}$ zapotrzebowaniu mężczyzn, którzy z niej w różny sposób korzystali. Kobiety należące do społecznej elity Rzymu korzystały z zabiegów termalnych w łaźniach prywatnych, gdzie nie bywały narażone na kontakty z obcymi mężczyznami, których nie pragnęłyby nawiązywać. W tureckich hammamach wszystkie rodzaje zabiegów odbywały się natomiast z uwzględnieniem 
podziału klientów według płci. Kobiety korzystały z hammamów w innych dniach lub godzinach niż mężczyźni. Były także obsługiwane przez kobiecy personel kąpielowy. Mężczyźni byli obsługiwani przez mężczyzn. Członkowie obu płci wypoczywali także po zabiegach wyłącznie w swoim towarzystwie.

Trzecią istotną różnicą był sposób spędzania czasu przez klientów hammamu po odbyciu zabiegów w salach przeznaczonych do wypoczynku. Ze starożytnego modelu kultury kąpielowej przejęto wzorzec, zgodnie z którym wypoczynek miał odbywać się we wnętrzach o wysokiej estetyce. W jego trakcie klienci mieli mieć możność obcowania ze sztuką oraz spożywania napojów i potraw dostosowanych do ich poziomu zamożności. W starożytnych termach rzymskich w salach wypoczynkowych do stałych elementów ich wyposażenia należały kopie rzeźb klasyków greckiej sztuki figuratywnej. Rzeźby te przedstawiały przeważnie nagie (lub ledwie osłonięte) ludzkie postacie obojga płci, przyczyniając się do upowszechniania wśród klientów klasycznych kanonów piękna. Potrawy oferowane klientom w rzymskich termach były zróżnicowane według lokalnych warunków (termy budowano bowiem na całym terytorium Cesarstwa Rzymskiego). Ich wspólnym elementem było spożywanie wina. W kulturze islamskiej było ono jednak zakazane. Dlatego klientom hammamów oferowano na zakończenie zabiegów kawę lub herbatę, a także wodę jako dodatek do różnych rodzajów potraw. Występowały wśród nich lokalne potrawy słodkie (np. baklawa) i owoce, które podawano na ozdobnych paterach lub tacach.

Powyższe czynniki znalazły swoje odzwierciedlenie w kolekcji Muzeum Hammamu, którą scharakteryzuję, korzystając z wykonanych przez siebie zdjęć.

Muzeum Hammamu Uniwersytetu w Stambule otwiera obszerny hall, w którego środku znajduje się fontanna. Był to tradycyjny element ich planu. Fontanna miała bowiem charakter nie tylko dekoracyjny. Można było $\mathrm{w}$ niej bowiem dokonać wstępnych ablucji rąk, a przede wszystkim nóg. Do dalszych pomieszczeń hammamu wchodzono bowiem boso, pozostawiając obuwie i odzież wierzchnią w znajdującej się w hallu szatni. Wychodzono z niej, już tylko okrywając ciało prześcieradłem, rozpoczynając zabiegi od prywatnych, indywidualnych obmywań i ablucji. W Muzeum Hammamu znajdują się przeznaczone do tego pomieszczenia, w których klienci myli się w miarę dokładnie sami. Dopiero mając tak oczyszczone ciała, mogli powierzyć wykonywanie dalszych zabiegów personelowi kąpielowe- 
mu. W salach do obmywań prywatnych zgromadzono różne pozostałości term rzymskich, znajdujących się na terenie Konstantynopola przed podbojem miasta przez Turków w $1453 \mathrm{r}$. Są to marmurowe wanny, fragmenty naczyń i urządzeń z terakoty itp. Istotna jest występująca w rzymskich termach stylistyka, nawiązująca do wzorców korynckich. W wielu tureckich hammamach, przy których budowie wykorzystano ruiny rzymskie, znajdujemy ich pozostałości, przede wszystkim korynckie kapitele kolumn i inne detale architektoniczne. Niektóre znalazły miejsce we wnętrzach hammamów, natomiast inne w otaczających je ogrodach.

Po wykonaniu indywidualnych ablucji klient hammamu poddawał się zabiegom oczyszczającym wykonywanym przez personel kąpielowy. Wstępne zabiegi odbywały się w pobliżu kranów z wodą płynącą, następne na specjalnym podeście, na którym kładł się klient, a kąpielowi obficie mydlili jego ciało, następnie usuwali brud za pomocą ręczników, skrobaczek lub gąbek. Ostatecznym etapem tego zabiegu było dokładne spłukanie ciała klienta, który mógł przejść już samodzielnie do sali, w której korzystał z zasadniczej procedury hamma$\mathrm{mu}$ - kąpieli w gorącej parze. Ze względu na brak dostatecznej ilości światła w pomieszczeniach do kąpieli parowych, nie mogę udokumentować ich wnętrz za pomocą fotografii. Są to w stambulskim Muzeum Hammamu wnętrza bardzo proste: wyłożone marmurem, ze specjalnymi otworami w ścianach, którymi bywała dostarczana para. Obok pomieszczeń do kąpieli parowych znajdowały się małe szatnie, w których klienci pozostawiali prześcieradła okrywające ich ciało.

Kamienne podesty kąpielowe, służące $\mathrm{w}$ hammanie do zabiegów oczyszczających z udziałem personelu kąpielowego, zostały wykorzystane w Muzeum stambulskim jako podstawa gablot, w których zaprezentowano utensylia kąpielowe: ręczniki, prześcieradła do okrywania ciała, a także specjalne obuwie na koturnach, z którego korzystano $\mathrm{w}$ trakcie kąpieli. Prezentowane w tych gablotach eksponaty cechuje wysoki poziom artyzmu. Ręczniki i prześcieradła są wykonane z bielonych naturalnych tkanin i ozdobione różnymi rodzajami haftów. Ekskluzywny charakter mają także eksponowane tu utensylia kąpielowe, wazony, kubki i dzbany do polewań. Wiele z nich zostało wykonanych ze srebra. Obuwie kąpielowe wykonane zostało z intarsjowanego drewna, a także ze srebra wysadzanego masą perłową.

Po skorzystaniu z łaźni parowej klient hammamu przechodził do pokoju do obmywań indywidualnych, w którym jeszcze raz dokładnie opłukiwał całe ciało, aż do uzyskania komfortu cieplnego (zaprzesta- 
nia obfitych potów). Oczyszczony i owinięty w świeże prześcieradło przechodził do pomieszczeń przeznaczonych do wypoczynku. Zgodnie z wzorcem czerpanym ze starożytnej kultury rzymskiej było to pomieszczenie o wysokich walorach estetycznych, w którym były eksponowane dzieła sztuki i podawane pokarmy i napoje.

W stambulskim Muzeum Hammamu znajdujemy elementy przykładowego wyposażenia sali do wypoczynku po zabiegach kąpielowych. W gablotach wystawiono kolekcje talerzy, kubków, dzbanów na wodę i serwetek używanych przy spożywaniu posiłków. W kolekcji zaprezentowano także porcelanowy serwis do kawy i herbaty wraz z kompletem naczyń do ich zaparzania. Brak jest natomiast klasycznych rzymskich naczyń używanych do serwowania wina, ponieważ klientom hammamów go nie podawano. Różni się także typ dzieł sztuki, które stanowiły integralne wyposażenie sali do wypoczynku. W Muzeum Hammamu brak jest występujących w rzymskich termach rzeźb figuratywnych, pojawiają się natomiast obrazy lub intarsje. Ten rodzaj eksponatów zakorzenia je na konkretnym etapie historii Imperium Osmańskiego, tj. w czasie od początków XIX w. do końca I wojny światowej i upadku rządzącej tym państwem dynastii. Upodobania artystyczne Osmanów zostały dokładnie wyrażone w architekturze i wyposażeniu wnętrz nowego pałacu sułtańskiego Dolmabahçe nad Bosforem. W odróżnieniu od starego pałacu sułtańskiego Topkapı we wnętrzach pałacu Dolmabahçe znajdują się liczne przykłady sztuki figuratywnej, zakazanej wcześniej w Turcji ze względów religijnych. Nie są to jednak rzeźby, ale obrazy, hafty i intarsje (np. masa perłowa w drewnie), przedstawiające naturalne pejzaże, morze i okręty. Te dwa ostatnie motywy pojawiają się szczególnie w latach 90. XIX w. i w okresie poprzedzającym wybuch I wojny światowej, kiedy to Turcja nawiązała sojusz wojskowy z Cesarstwem Niemieckim, którego elementem była budowa floty wojennej. W stambulskim Muzeum Hammamu znajdujemy liczne przykłady obrazów i intarsji o tematyce morskiej, wykonanych w różnych technikach i o różnym stopniu realizmu. Są to zarówno stylizowane przedstawienia figuratywne, przedstawiających obok statków także ludzkie postaci - w tej samej konwencji, którą zastosowano w miniaturach medycznych, jak i obrazy na kaflach lub wykonane techniką haftu srebrną nicią na jedwabiu.

Ogólna ocena ekspozycji Muzeum Hammamu jest wysoka. Twórcom wystawy udało się stworzyć przemyślany plan wystawy i w pełni zrealizować cele, które przed sobą postawili. Zwiedzający poznają 
Wybrane kolekcje historyczne z zakresu historii medycyny i farmacji...

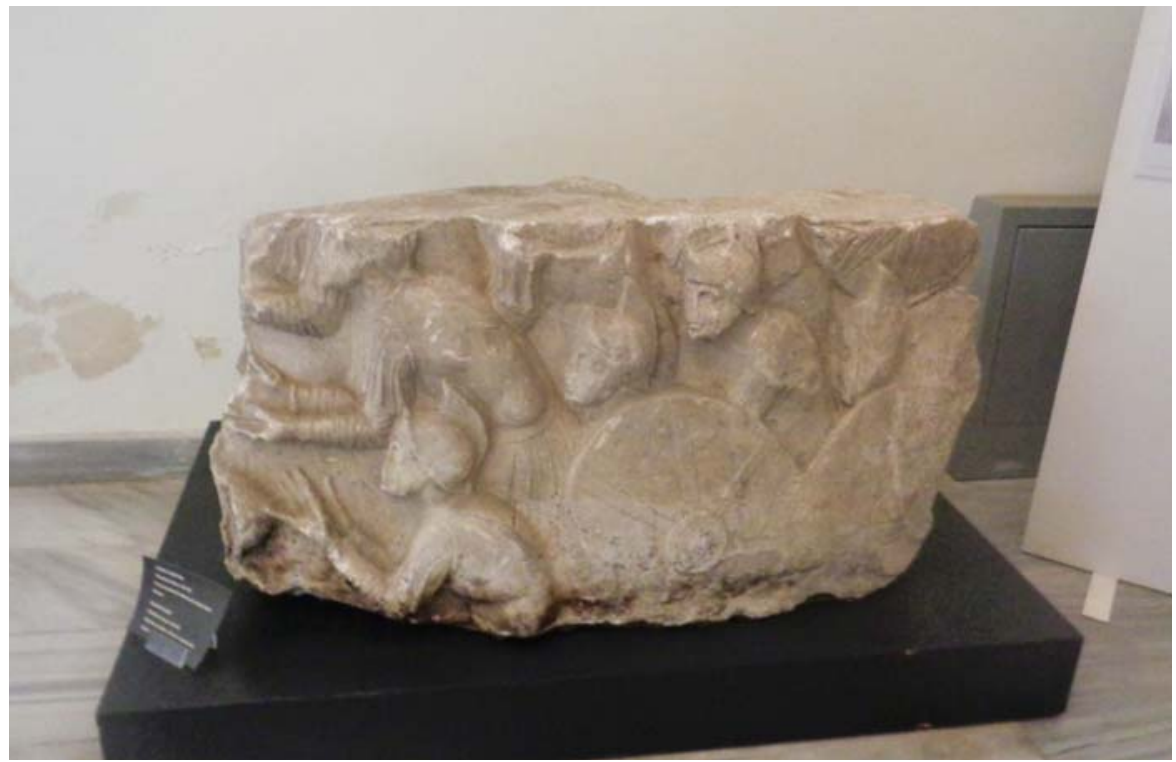

Fot. 18. Fragment term z czasów rzymskich

Źródło: Fot. B. Płonka-Syroka (2018).

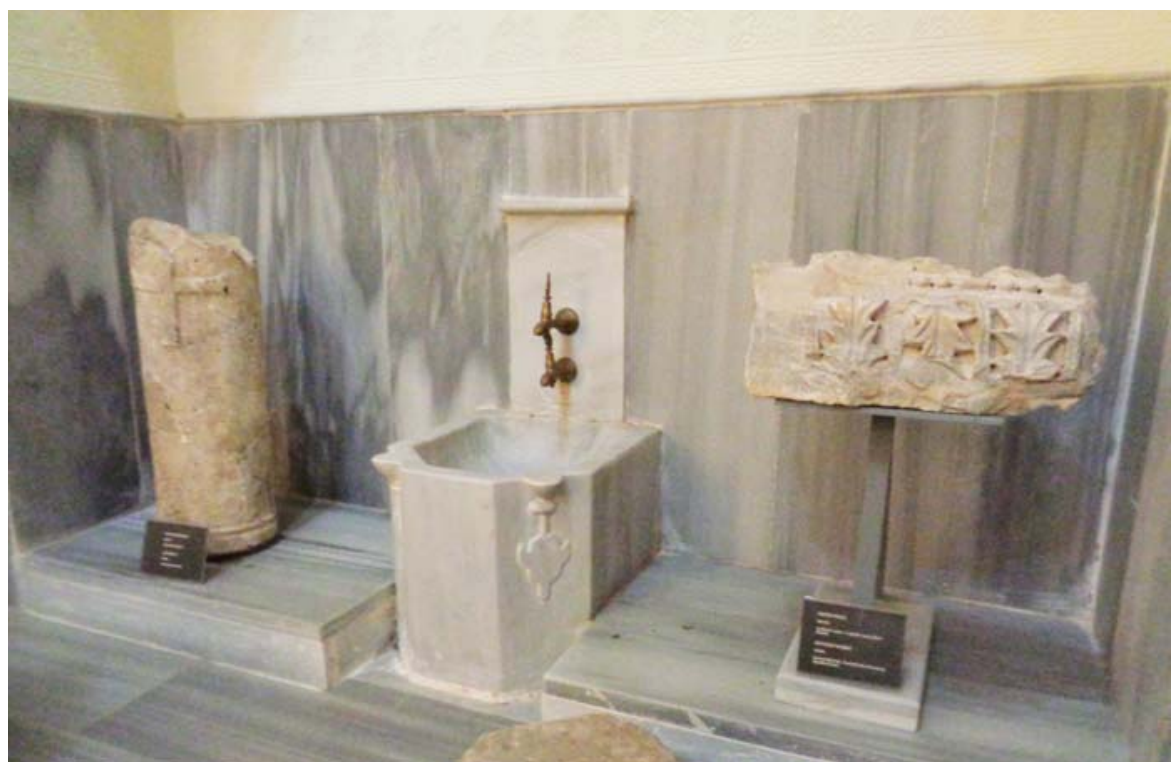

Fot. 19. Inne fragmenty term $z$ czasów rzymskich

Źródło: Fot. B. Płonka-Syroka (2018). 


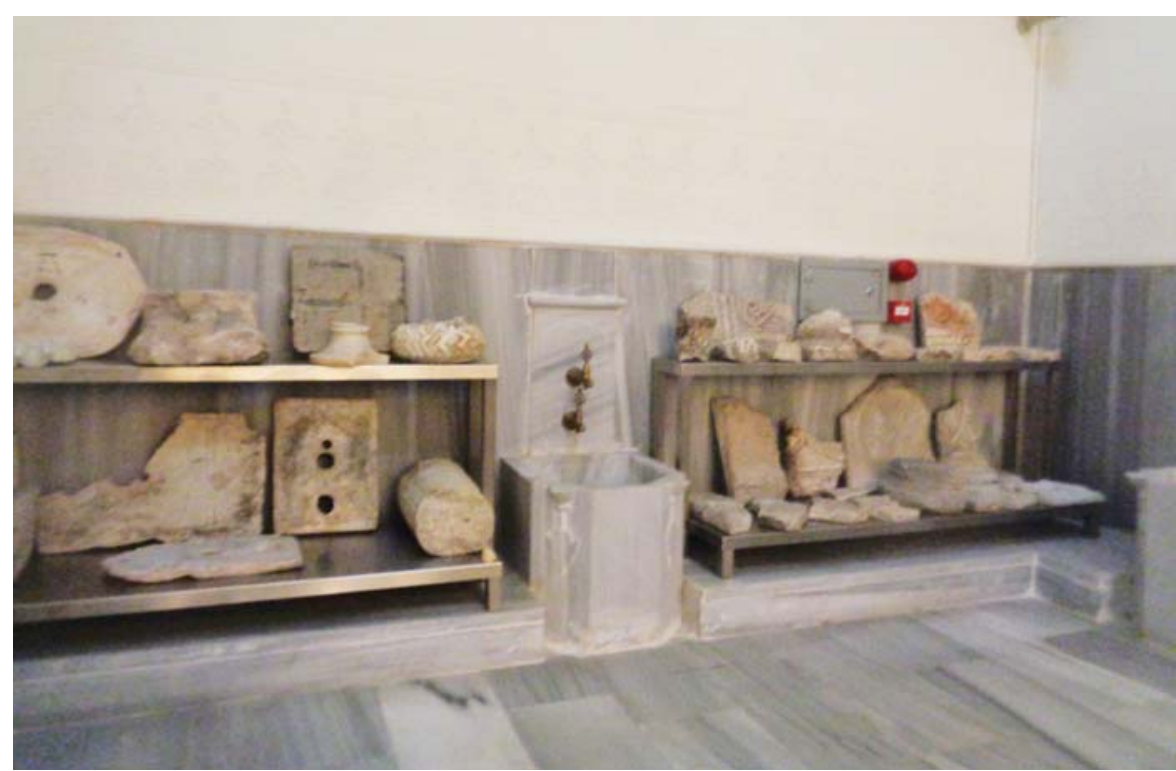

Fot. 20. Elementy architektury i urządzeń kąpielowych term rzymskich Źródło: Fot. B. Płonka-Syroka (2018).

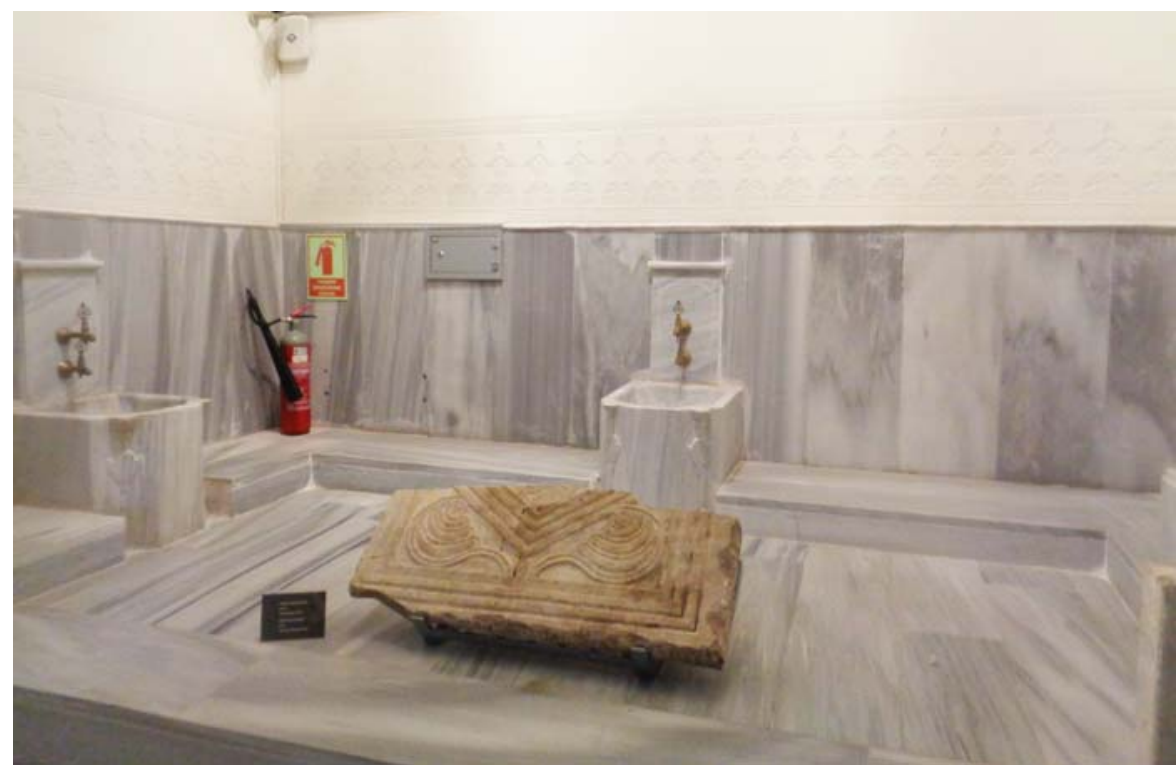

Fot. 21. Turecki hammam - sala do wstępnych ablucji indywidualnych Źródło: Fot. B. Płonka-Syroka (2018). 
Wybrane kolekcje historyczne z zakresu historii medycyny i farmacji...

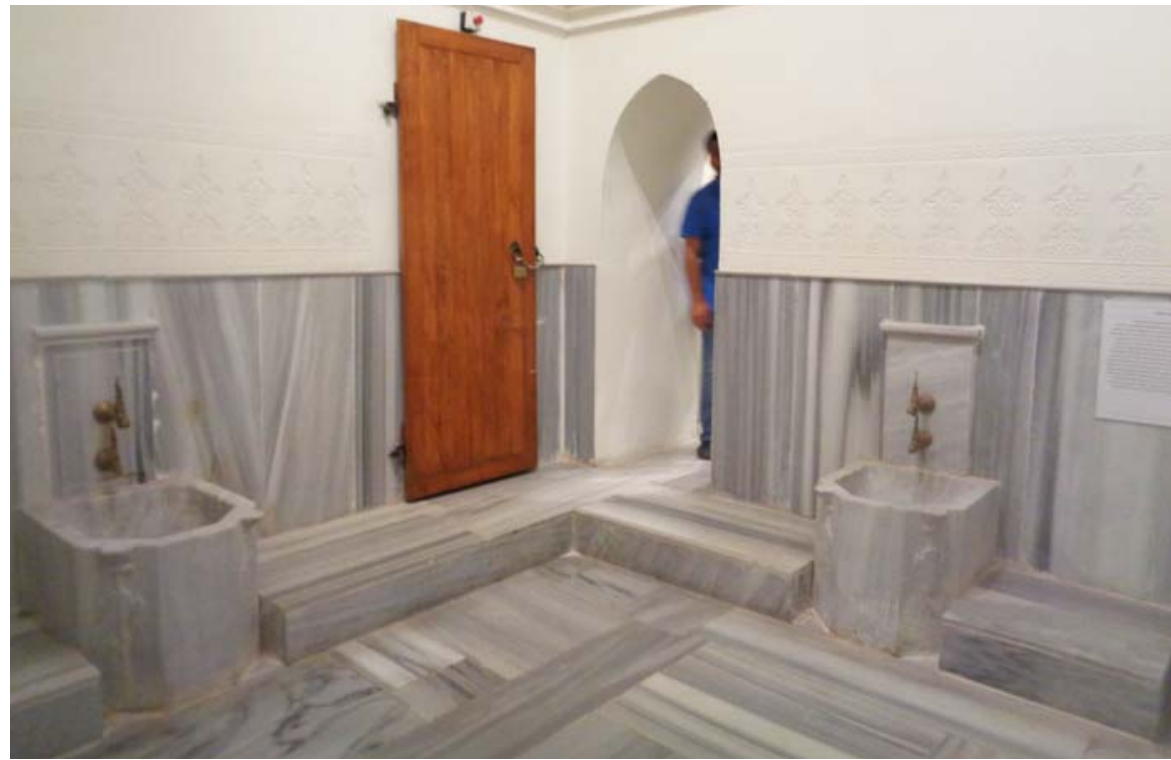

Fot. 22. Pokój do końcowych obmywań indywidualnych Źródło: Fot. B. Płonka-Syroka (2018).

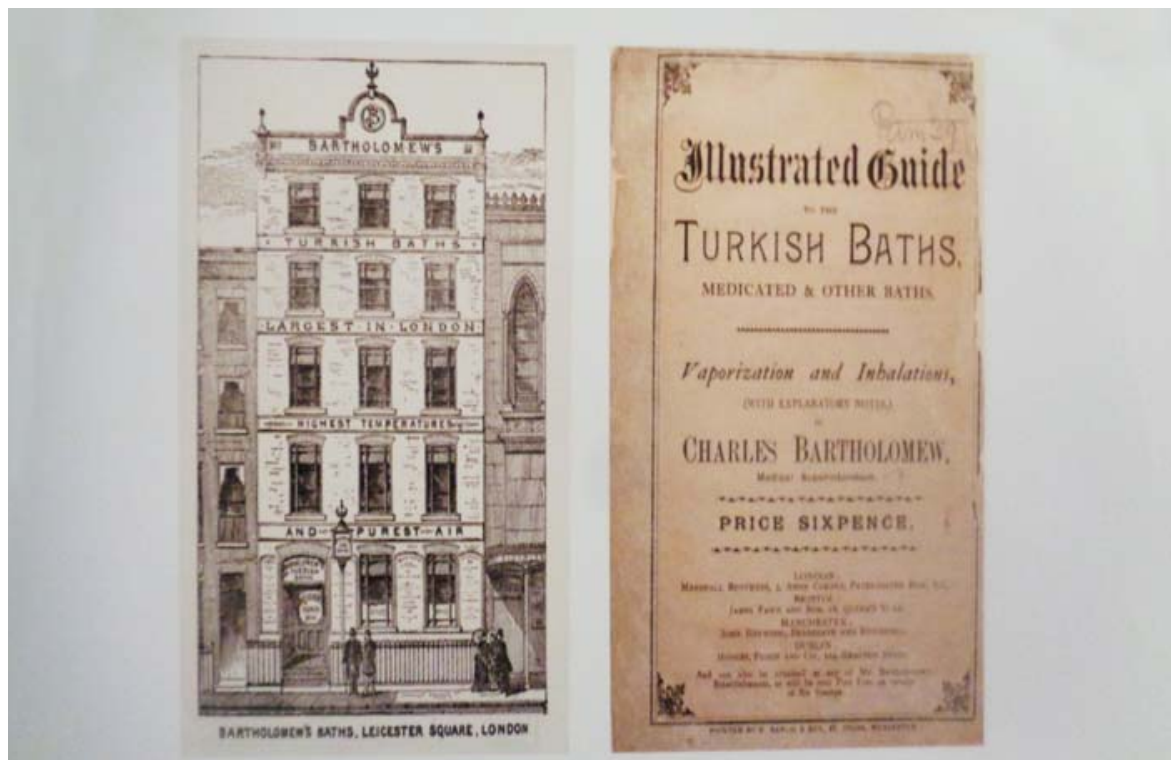

Fot. 23. Angielski przewodnik po łaźniach tureckich wydany w Londynie w $1887 \mathrm{r}$.

Źródło: Fot. B. Płonka-Syroka (2018). 


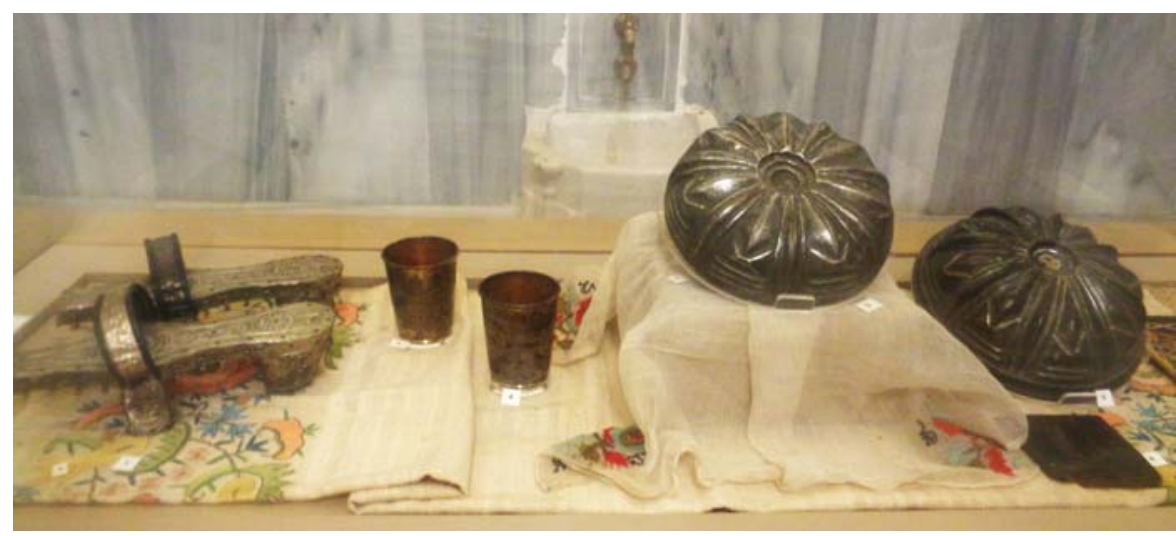

Fot. 24. Buty na koturnach używane w hammamie, naczynia i ręczniki ozdobione haftem z motywem tulipanów

Źródło: Fot. B. Płonka-Syroka (2018).

w trakcie zwiedzania tej ekspozycji zarówno starożytne źródła tureckiej kultury kąpielowej, jak i zapoznają się z jej specyfiką. Korzystanie $\mathrm{z}$ hammamu jest przedstawiane jako praktyka medyczna i higieniczna, a zarazem jako ważne narzędzie identyfikacji kulturowej Turków. Jako element ich stylu życia i kultury dnia codziennego. Jednak nie tylko. Eksponaty zaprezentowane w sali do wypoczynku, zbieżne z islamskim światopoglądem i respektujące związane z nim ograniczenia (zakaz spożywania wina, zakaz przedstawiania rzeźb figuratywnych i naturalistycznych obrazów ludzkich postaci), otwierają publiczności perspektywę akceptowaną przez rodzimą, turecką tradycję i estetykę, zakorzenioną w standardzie rodzimej kultury. Jest to przestrzeń kulturowa, której nie odbieramy jako uboższą od rzymskiej, ale po prostu jako inną. Eksponaty zostały tak dobrane, aby umożliwić publiczności dostęp do tureckiego kanonu piękna. Wysoki poziom estetyczny eksponatów sprawia, że trzeba uznać to zamierzenie twórców ekspozycji za udane. Na wystawie zostały zaprezentowane zbiory oddające stylistykę charakterystyczną dla tureckiej kultury wyższej. Odmienność od europejskich kanonów nie jest tu realizowana za pośrednictwem afirmacji rodzimej kultury ludowej, której przykładów w stambulskim Muzeum Hammamu nie spotykamy, podobnie jak w innych tureckich muzeach związanych z historią medycyny. 
Wybrane kolekcje historyczne z zakresu historii medycyny i farmacji...

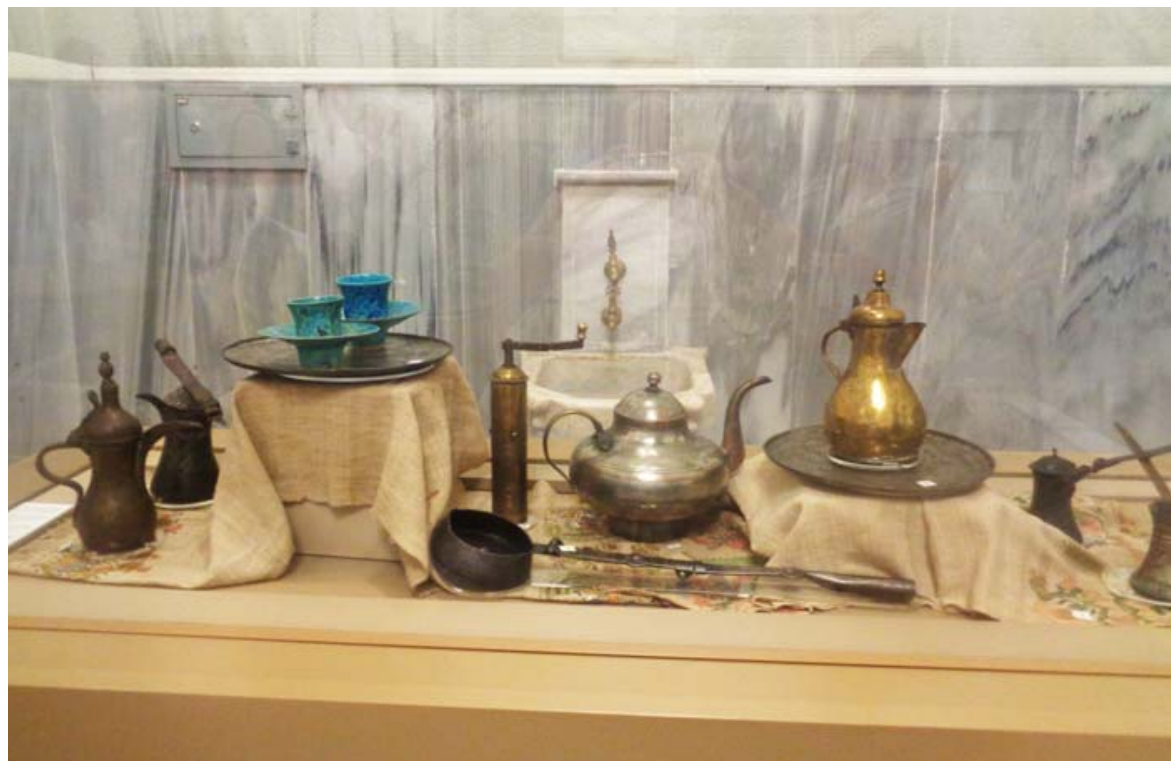

Fot. 25. Porcelanowy serwis do kawy lub herbaty wraz z kompletem naczyń do ich zaparzania

Źródło: Fot. B. Płonka-Syroka (2018).

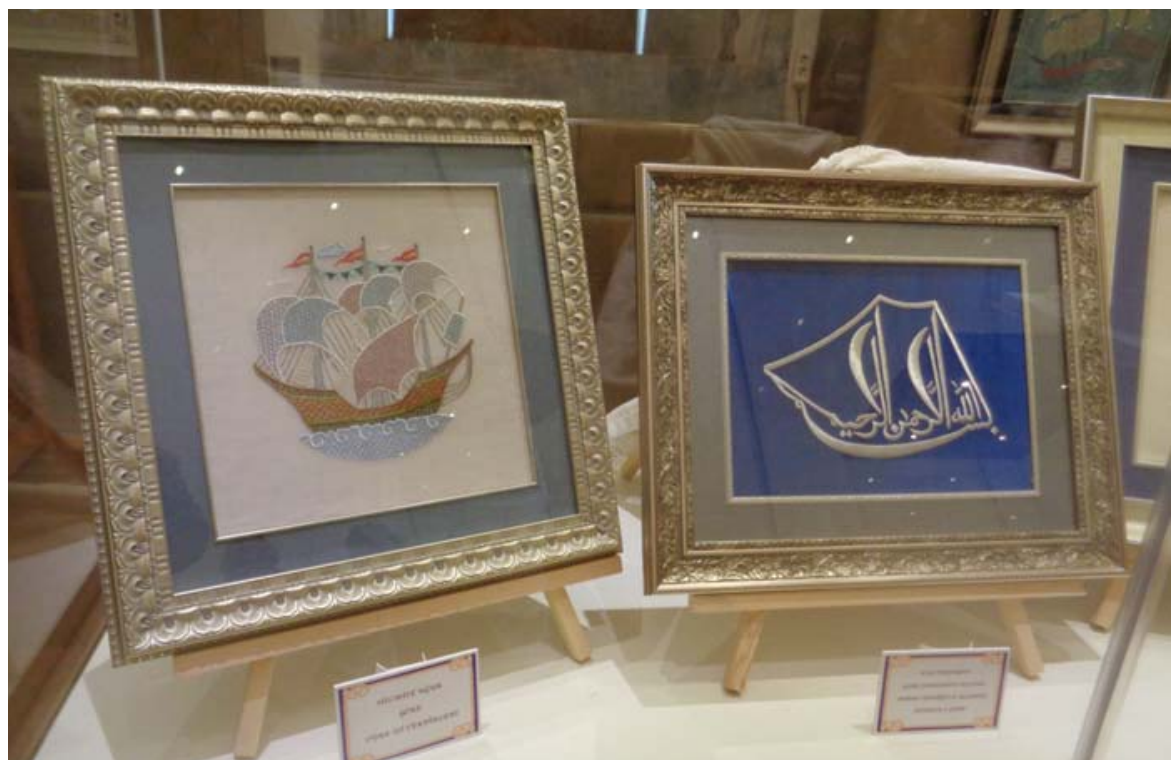

Fot. 26. Fragment kolekcji o tematyce morskiej znajdującej się w hammamie w sali do wypoczynku

Źródło: Fot. B. Płonka-Syroka (2018). 


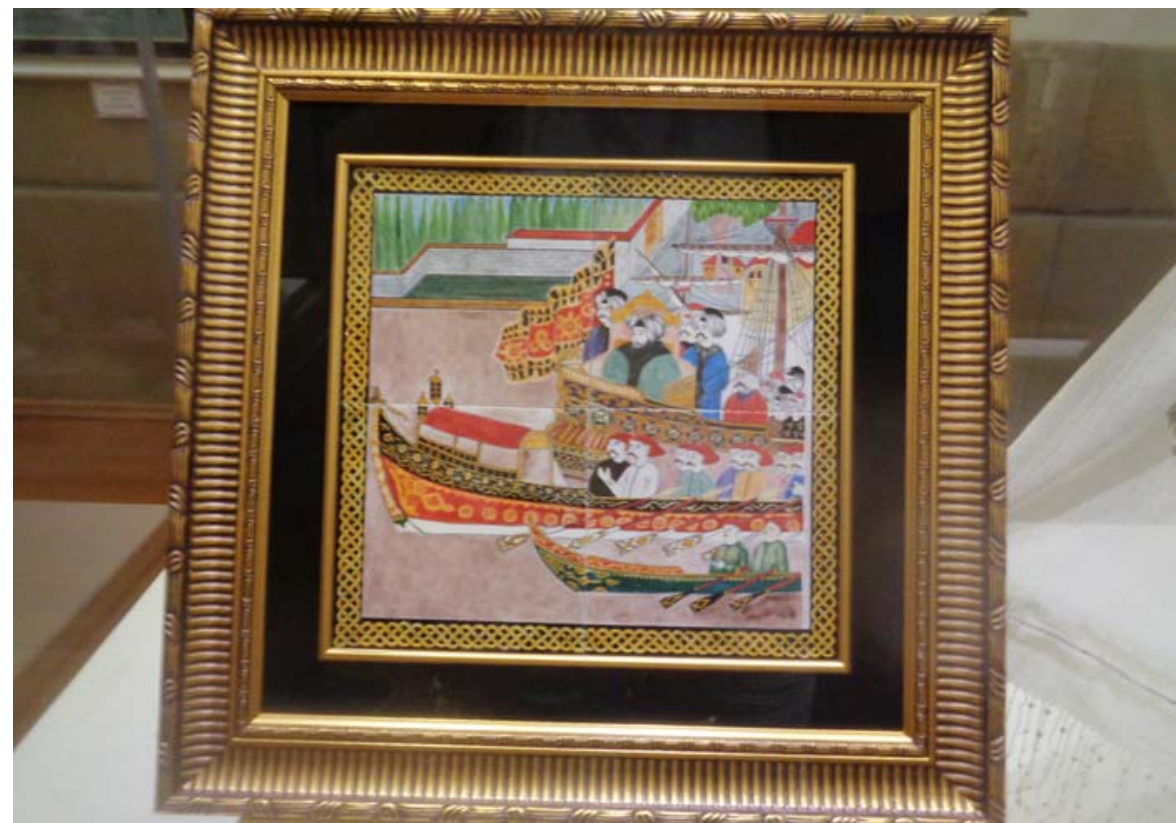

Fot. 27. Miniatura dawnej floty islamskiej znajdująca się w sali do wypoczynku

Źródło: Fot. B. Płonka-Syroka (2018).

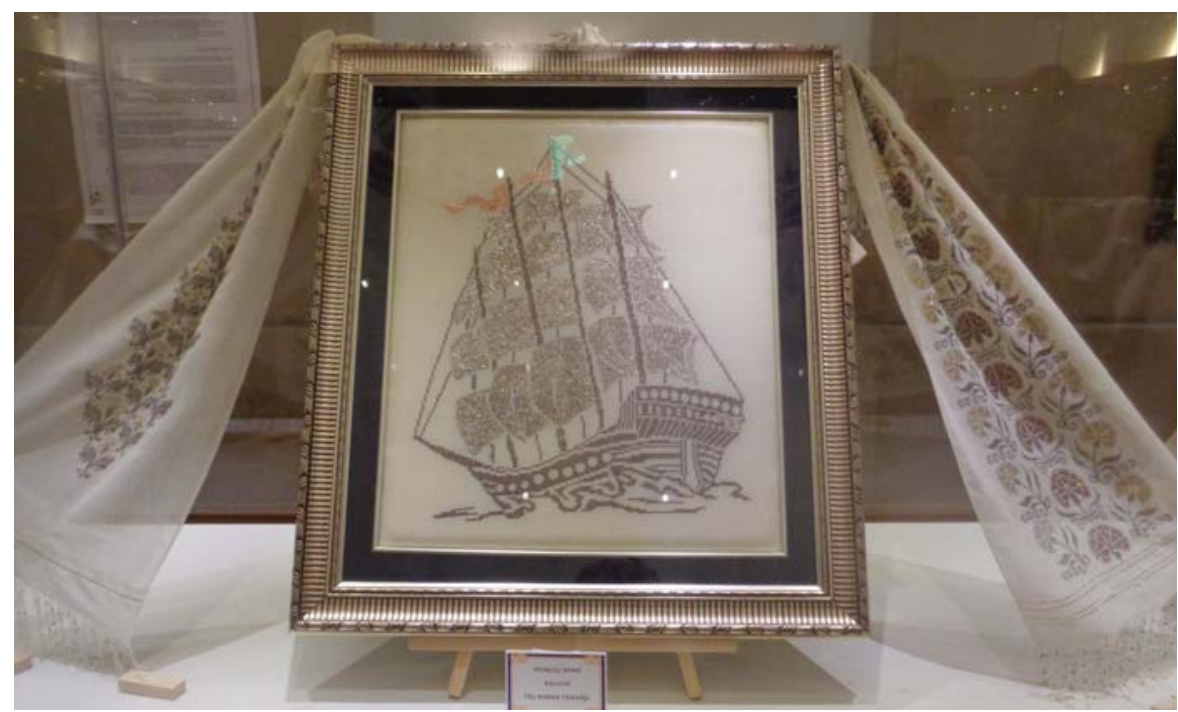

Fot. 28. Stylizowany statek wyhaftowany srebrną nicią na jedwabiu znajdujący się w sali do wypoczynku

Źródło: Fot. B. Płonka-Syroka (2018). 


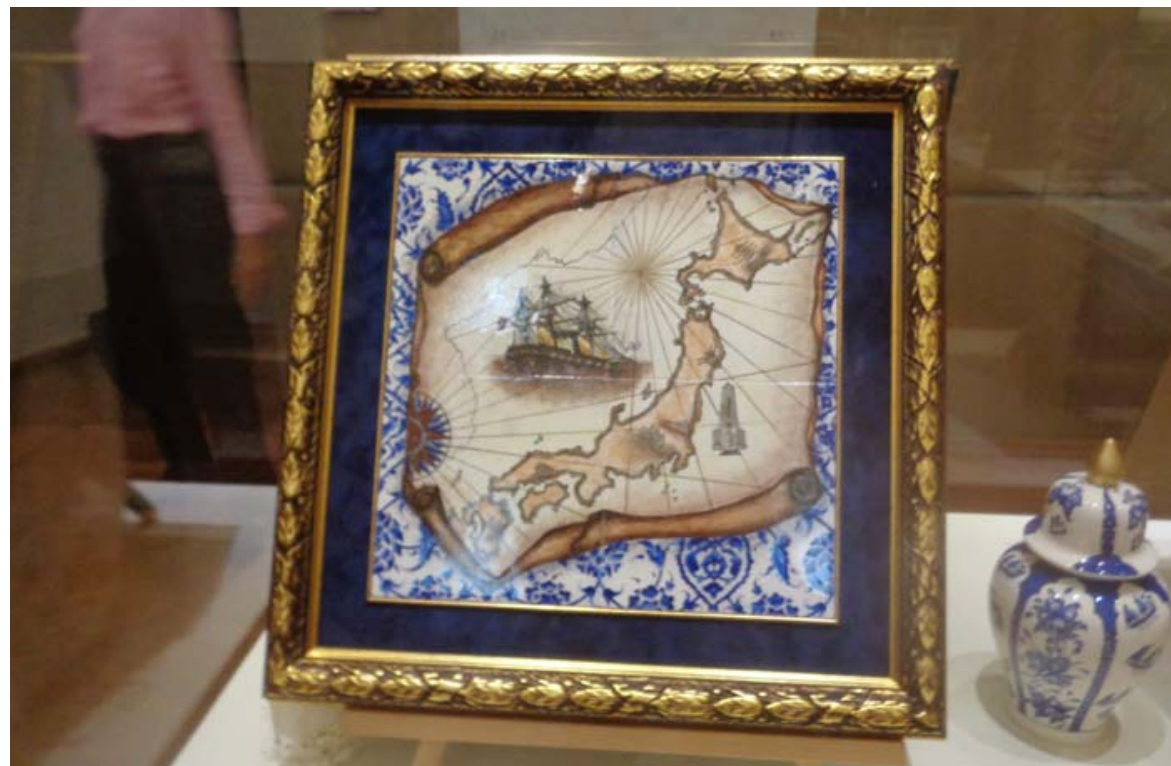

Fot. 29. Ozdobny porcelanowy kafel z motywem podróży morskiej i porcelanowy wazon - fragment ekspozycji w sali do wypoczynku Źródło: Fot. B. Płonka-Syroka (2018).

\section{Podsumowanie}

Zaprezentowane $\mathrm{w}$ niniejszym artykule muzea, związane tematycznie $\mathrm{z}$ historią medycyny i farmacji, są rzadko odwiedzane przez polskich zwiedzających, w tym polskich historyków tych dziedzin nauki. Tym bardziej zasługuja na upowszechnienie podstawowych informacji o nich, które być może skłonią polskich naukowców do ich odwiedzenia.

W następnych częściach artykułu postaram się scharakteryzować kolejne kolekcje muzealne Stambułu, w tym te, które nie są szerzej dostępne dla zwiedzających. Wspólnym elementem tych kolekcji jest będące podstawą ich scenariuszy wystawienniczych poczucie europejskości charakterystyczne dla sposobu przedstawiania tureckiej i - szerzej - islamskiej myśli i praktyki naukowej. Europejskość ta wywodzona jest ze wspólnoty korzeni całej śródziemnomorskiej cywilizacji, która w obrębie nauk przyrodniczych rozwija się w tym samym kierunku, przy nieustannej wymianie koncepcji naukowych między chrześcijańskim i islamskim kręgiem kulturowym. W ujęciu tureckiej myśli historycznej korzenie te są nie tylko greckie, lecz także egipskie, a wymiana 
koncepcji naukowych zachodziła w sposób dwukierunkowy: zarówno z Europy Zachodniej na Wschód, jak i ze Wschodu na Zachód. Ten ostatni kierunek nie jest jednak jeszcze dostatecznie przebadany.

\section{Bibliografia}

Alkan E., Current Reflections of the Turkish Bath Culture, [w:] A. Namal, A.D. Erdemir, B. Płonka-Syroka (red.), Tarihte saglik ve Su kültürü / Gesundheit und Wasserkultur in der Geschichte / Health and Water-Culture in History, Istanbul Medical Saglik ve Yayincilik Hiz. Tic. Ltd., Istanbul 2016.

Baran D., Turkish Baths in the Romanian Principalities, [w:] A.D. Erdemir, S. Erer, Ö. Usmanbas, B. Akgün (red.), 5th Balkan Congress on the History \& Ethics of Medicine 11-15 October 2011 Istanbul. Abstracts and Proceedings Book, Nobel Tip Kitabevleri Ltd., Istanbul 2012.

Cantay G.G., Hammam - Thermal Spring (Terms, Architekture, Bathing, Healing), [w:] A. Namal, A.D. Erdemir, B. Płonka-Syroka (red.), Tarihte saglik ve Su kültürü / Gesundheit und Wasserkultur in der Geschichte / Health and Water-Culture in History, Istanbul Medical Saglik ve Yayincilik Hiz. Tic. Ltd., Istanbul 2016.

Erbay F., Istanbul Exhibitions as a Rescue for the History of Medicine, [w:] A.D. Erdemir, S. Erer, Ö. Usmanbas, B. Akgün (red.), 5th Balkan Congress on the History \& Ethics of Medicine 11-15 October 2011 Istanbul. Abstracts and Proceedings Book, Nobel Tip Kitabevleri Ltd., Istanbul 2012.

Erbay F., The Role of Medical Museum in the Education of Medicine, [w:] A. Musajo-Somma (red.), The 39th International Society of History of Medicine Congress on the History of Medicine 5-10 September 2004, Italia, Bari 2005.

Gültekin E., Geschichte der modernen Hydrotherapie in der Türkey mit einigen originalen Beiträgen, [w:] A. Namal, A.D. Erdemir, B. Płonka-Syroka (red.), Tarihte saglik ve Su kültürü / Gesundheit und Wasserkultur in der Geschichte / Health and Water-Culture in History, Istanbul Medical Saglik ve Yayincilik Hiz. Tic. Ltd., Istanbul 2016.

Kernbauer A., Die Beziehungen österreichischer Universitäten, im besonderen jener von Prag und Graz, zur Universität Istanbul, [w:] A. Terzioglu (red.), Proceedings of the Internationl Symposium: Istanbul University and the European Universities on the Occasion ot the 550th Anniversary of the Foundation of Istanbul University, University of Istanbul, Istanbul 2004. 
Namal A., Turkish baths in history and their place in daily life, [w:] B. Płonka-Syroka, A. Kaźmierczak, S. Jandziś, A. Syroka (red.), Tradycje i perspektywy rozwoju kultury uzdrowiskowej w Iwoniczu-Zdroju $w$ kontekście europejskim, Kultura uzdrowiskowa w Europie, t. 10, Oficyna Wydawnicza Arboretum, Wrocław 2018.

Öztürk Y., A Virtual Historical Museum: the Case of Historical Sihhat Pharmacy (Tarihi Sihhat Eczanesi) in the Faculty of Anadolu University, [w:] A. Mat, H. Tekiner, B. Sen (red.), The Exchange of Pharmaceutical Knowledge between East and West. Proceedings 42nd International Congress for the History of Pharmacy 8-11 September 2015 Istanbul, Maestro Advertising Co., Istanbul 2016.

Płonka-Syroka B., Kolekcja miniatur islamskich w zbiorach Muzeum Farmacji Uniwersytetu Medycznego im. Piastów Ślaskich we Wrocławiu, [w:] A. Marek, B. Urbanek (red.), Rozwój aptekarstwa ślaskiego: moda i styl $w$ aptekach polskich ze szczególnym uwzględnieniem Ślaska i jego specyfiki, Śląski Uniwersytet Medyczny, Katowice 2014.

Płonka-Syroka B., Medycyna islamska $w$ świetle średniowiecznych miniatur medycznych, [w:] B. Płonka-Syroka, Ł. Braun (red.), Kultura medyczna islamu, Wydawnictwo DiG, Warszawa 2015.

Sari N., Hydrotherapy as descripted in Ottoman Medical Manuscripts, [w:] A. Namal, A.D. Erdemir, B. Płonka-Syroka (red.), Saglik ve Su Kültürü / Gesundheit und Wasserkultur / Health and Water-Culture, Birinci Baski, Istanbul 2014.

Savage-Smith E., Medycyna, [w:] R. Rashed (red.), Historia nauki arabskiej, t. 3. Technika, alchemia, nauki przyrodnicze i medycyna, tłum. J. Kozłowska, K. Pachniak, Wydawnictwo Dialog, Warszawa 2005.

Sen B., Deutsch-Türkische Beziehungen in der Pharmazie, [w:] A. Mat, H. Tekiner, B. Sen (red.), The Exchange of Pharmaceutical Knowledge between East and West. Proceedings 42nd International Congress for the History of Pharmacy 8-11 September 2015 Istanbul, Maestro Advertising Co., Istanbul 2016.

Sen B., Nicolas M., Mat A., Les Relations Academiques en Pharmacie entre la France et la Turqie, [w:] A. Mat, H. Tekiner, B. Sen (red.), The Exchange of Pharmaceutical Knowledge between East and West. Proceedings 42nd International Congress for the History of Pharmacy 8-11 September 2015 Istanbul, Maestro Advertising Co., Istanbul 2016. 
Sezgin F., The Istanbul Museum for the History of Science and Technology in Islam (An Overview), Culture Co., Istabul 2010.

Szymański P.R., Termy, między sacrum i profanum, [w:] B. Płonka-Syroka, M. Dąsal, A. Syroka (red.), Tradycje i perspektywy rozwoju kultury uzdrowiskowej $w$ Województwie Świętokrzyskim w kontekście europejskim, Kultura uzdrowiskowa w Europie, t. 7, Oficyna Wydawnicza Arboretum, Wrocław 2016.

Terzioglu A., Lucius E. (red.),Österreichisch-Türkische Medizinische Beziehungen. Berichte des Symposiums von 28. und 29. April 1986 in Istanbul, University of Istanbul, Istanbul 1987.

Wolny M., Wiedza medyczna w starożytnym Rzymie (III w. p.n.e.-I w. n.e.) jako podtoże kultury uzdrowiskowej w Imperium Romanum, [w:] B. Płonka-Syroka, A. Kaźmierczak (red.), Historia kultury uzdrowiskowej w Europie, t. 1, Oficyna Wydawnicza Arboretum, Wrocław 2012. 